\title{
LEVEL II SCOUR ANALYSIS FOR BRIDGE 23 (HARDTH00530023) on TOWN HIGHWAY 53, crossing HAYNESVILLE BROOK, HARDWICK, VERMONT
}

U.S. Geological Survey Open-File Report 96-638

Prepared in cooperation with

VERMONT AGENCY OF TRANSPORTATION and

FEDERAL HIGHWAY ADMINISTRATION 


\section{LEVEL II SCOUR ANALYSIS FOR BRIDGE 23 (HARDTH00530023) on TOWN HIGHWAY 53, crossing HAYNESVILLE BROOK, HARDWICK, VERMONT \\ By SCOTT A. OLSON}

U.S. Geological Survey Open-File Report 96-638

Prepared in cooperation with

VERMONT AGENCY OF TRANSPORTATION and

FEDERAL HIGHWAY ADMINISTRATION 


\title{
U.S. DEPARTMENT OF THE INTERIOR BRUCE BABBITT, Secretary
}

\author{
U.S. GEOLOGICAL SURVEY \\ Gordon P. Eaton, Director
}

For additional information write to:

District Chief

U.S. Geological Survey 361 Commerce Way

Pembroke, NH 03275-3718
Copies of this report may be purchased from:

U.S. Geological Survey

Branch of Information Services

Open-File Reports Unit

Box 25286

Denver, CO 80225-0286 


\section{CONTENTS}

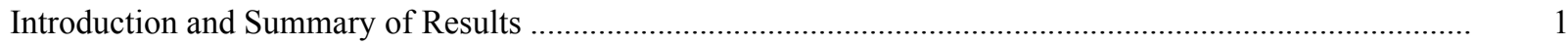

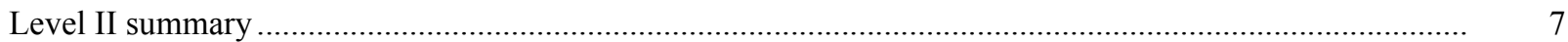

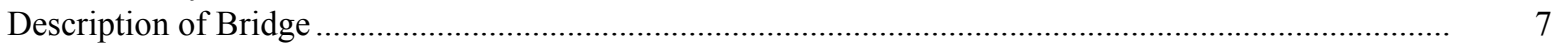

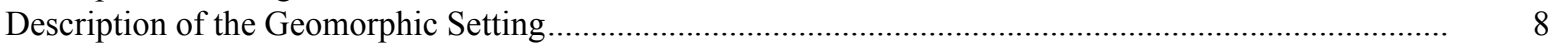

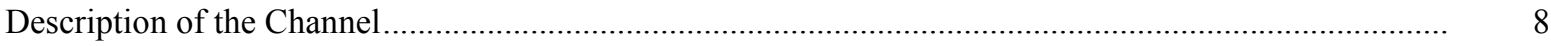

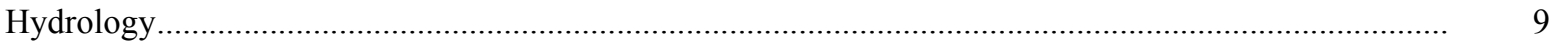

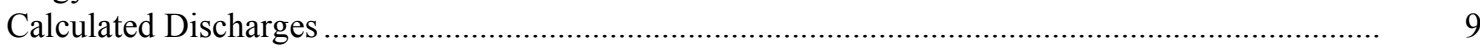

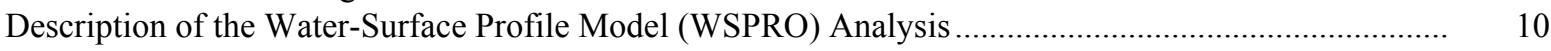

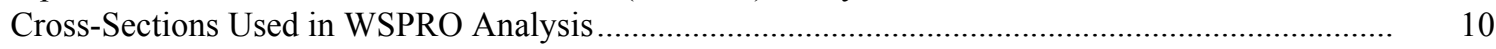

Data and Assumptions Used in WSPRO Model ...................................................................... 11

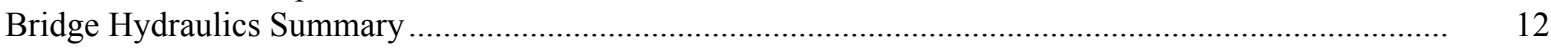

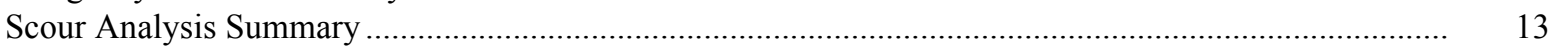

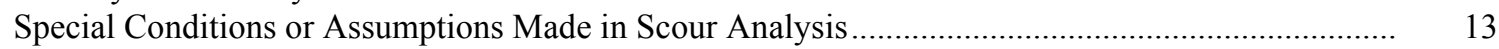

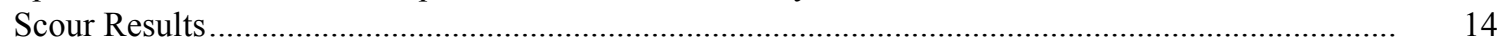

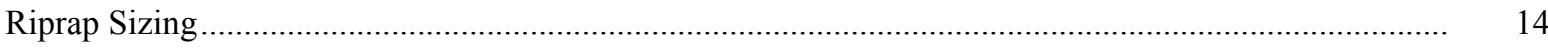

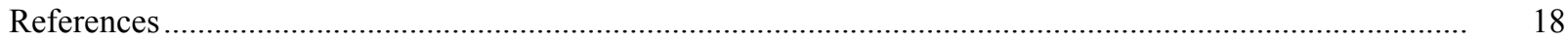

Appendixes:

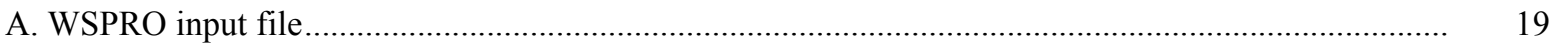

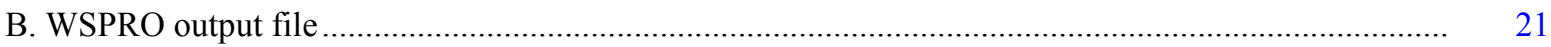

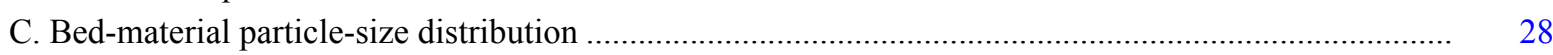

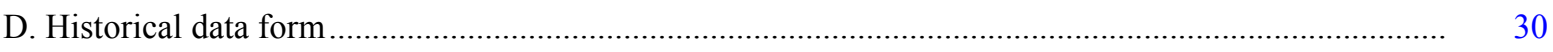

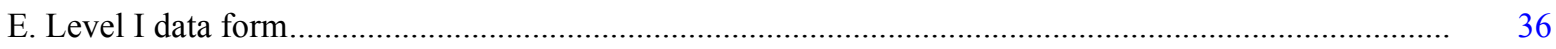

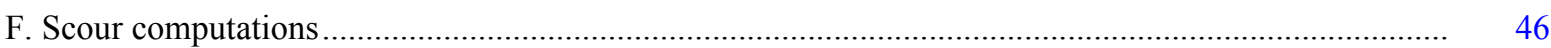

\section{FIGURES}

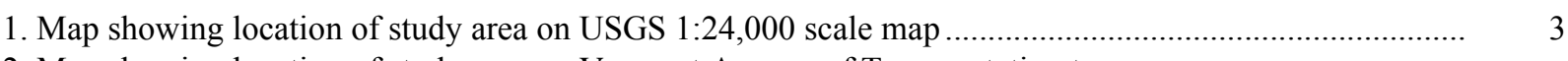

2. Map showing location of study area on Vermont Agency of Transportation town
highway map

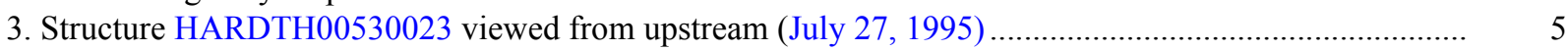

4. Downstream channel viewed from structure HARDTH00530023 (July 27, 1995). .............................. 5

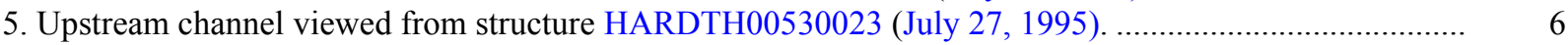

6. Structure HARDTH00530023 viewed from downstream (July 27, 1995)......................................... 6

7. Water-surface profiles for the 100- and 500-year discharges at structure

HARDTH00530023 on Town Highway 53, crossing Haynesville Brook,

Hardwick, Vermont.

8. Scour elevations for the 100- and 500-year discharges at structure

HARDTH00530023 on Town Highway 53, crossing Haynesville Brook,

Hardwick, Vermont.

\section{TABLES}

1. Remaining footing/pile depth at abutments for the 100-year discharge at structure

HARDTH00530023 on Town Highway 53, crossing Haynesville Brook,

Hardwick, Vermont.

2. Remaining footing/pile depth at abutments for the 500-year discharge at structure

HARDTH00530023 on Town Highway 53, crossing Haynesville Brook,

Hardwick, Vermont.

5




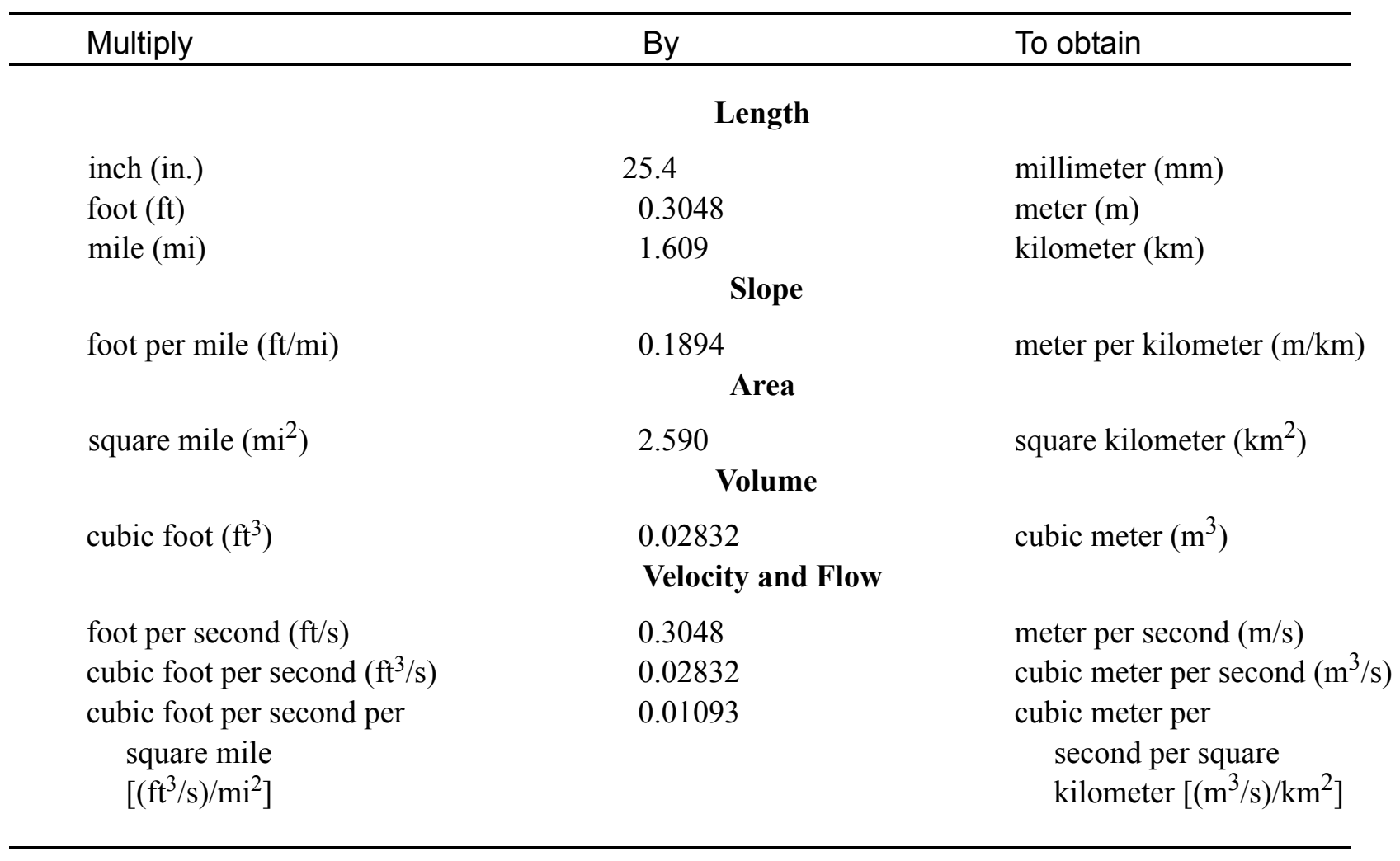

\section{OTHER ABBREVIATIONS}

$\begin{array}{lrlr}\mathrm{BF} & \text { bank full } & \text { LWW } & \text { left wingwall } \\ \mathrm{cfs} & \text { cubic feet per second } & \text { MC } & \text { main channel } \\ \mathrm{D}_{50} & \text { median diameter of bed material } & \text { RAB } & \text { right abutment } \\ \mathrm{DS} & \text { downstream } & \text { RABUT } & \text { face of right abutment } \\ \mathrm{elev} & \text { elevation } & \text { RB } & \text { right bank } \\ \mathrm{f} / \mathrm{p} & \text { flood plain } & \text { ROB } & \text { right overbank } \\ \mathrm{ft}^{2} & \text { square feet } & \text { RWW } & \text { right wingwall } \\ \mathrm{ft} / \mathrm{ft} & \text { feet per foot } & \text { TH } & \text { town highway } \\ \mathrm{JCT} & \text { junction } & \text { UB } & \text { under bridge } \\ \mathrm{LAB} & \text { left abutment } & \text { US } & \text { upstream } \\ \mathrm{LABUT} & \text { face of left abutment } & \text { USGS } & \text { United States Geological Survey } \\ \mathrm{LB} & \text { left bank } & \text { VTAOT Vermont Agency of Transportation } \\ \mathrm{LOB} & \text { left overbank } & \text { WSPRO } & \text { water-surface profile model }\end{array}$

In this report, the words "right" and "left" refer to directions that would be reported by an observer facing downstream. Sea level: In this report, "sea level" refers to the National Geodetic Vertical Datum of 1929-- a geodetic datum derived from a general adjustment of the first-order level nets of the United States and Canada, formerly called Sea Level Datum of 1929.

In the appendices, the above abbreviations may be combined. For example, USLB would represent upstream left bank. 


\title{
LEVEL II SCOUR ANALYSIS FOR BRIDGE 23 (HARDTH00530023) ON TOWN HIGHWAY 53, CROSSING HAYNESVILLE BROOK, HARDWICK, VERMONT
}

\author{
By Scott A. Olson
}

\section{INTRODUCTION AND SUMMARY OF RESULTS}

This report provides the results of a detailed Level II analysis of scour potential at structure HARDTH00530023 on Town Highway 53 crossing Haynesville Brook, Hardwick, Vermont (figures 1-8). A Level II study is a basic engineering analysis of the site, including a quantitative analysis of stream stability and scour (U.S. Department of Transportation, 1993). Results of a Level I scour investigation also are included in Appendix E of this report. A Level I investigation provides a qualitative geomorphic characterization of the study site. Information on the bridge, gleaned from Vermont Agency of Transportation (VTAOT) files, was compiled prior to conducting Level I and Level II analyses and is found in Appendix D.

The site is in the New England Upland section of the New England physiographic province in north-central Vermont. The $14.2-\mathrm{mi}^{2}$ drainage area is in a predominantly rural and forested basin. In the vicinity of the study site, the predominate surface cover consists of field grasses except for the upstream left bank with is brush covered.

In the study area, Haynesville Brook has a sinuous channel with a slope of approximately $0.004 \mathrm{ft} / \mathrm{ft}$, an average channel top width of $39 \mathrm{ft}$ and an average channel depth of $2 \mathrm{ft}$.

Stream-bed material at the site ranged from silt to gravel with a median grain size $\left(\mathrm{D}_{50}\right)$ of $49.9 \mathrm{~mm}(0.164 \mathrm{ft})$. The geomorphic assessment at the time of the Level I and Level II site visit on July 27,1995 , indicated that the reach was laterally unstable. Channel scour in both the upstream and downstream reaches as well as irregular point bars and cut banks and upstream anabranching led to this assessment.

The Town Highway 53 crossing of Haynesville Brook is a 33-ft-long, one-lane bridge consisting of one 26-foot steel-beam span (Vermont Agency of Transportation, written communication, March 24, 1994). The bridge is supported by vertical, concrete abutments with no wingwalls. The concrete may be facing over the original stone abutments. Sheet piling has been driven around the base of each abutment and is filled with concrete. The channel is skewed approximately 10 degrees to the opening; the opening-skew-to-roadway is also 10 degrees. Additional details describing conditions at the site are included in the Level II Summary and Appendices D and E. 
Scour depths and rock rip-rap sizes were computed using the general guidelines described in Hydraulic Engineering Circular 18 (Richardson and others, 1995). Total scour at a highway crossing is comprised of three components: 1) long-term streambed degradation; 2) contraction scour (due to accelerated flow caused by a reduction in flow area at a bridge) and; 3) local scour (caused by accelerated flow around piers and abutments). Total scour is the sum of the three components. Equations are available to compute depths for contraction and local scour and a summary of the results of these computations follows.

Contraction scour for all modelled flows ranged from 0.0 to $2.0 \mathrm{ft}$. The worst-case contraction scour occurred at the 100-year discharge. Abutment scour ranged from 7.0 to $12.9 \mathrm{ft}$. The worst-case abutment scour occurred at the 500-year discharge. Additional information on scour depths and depths to armoring are included in the section titled "Scour Results". Scoured-streambed elevations, based on the calculated scour depths, are presented in tables 1 and 2. A cross-section of the scour computed at the bridge is presented in figure 8. Scour depths were calculated assuming an infinite depth of erosive material and a homogeneous particle-size distribution.

It is generally accepted that the Froehlich equation (abutment scour) gives "excessively conservative estimates of scour depths" (Richardson and others, 1995, p. 47). Usually, computed scour depths are evaluated in combination with other information including (but not limited to) historical performance during flood events, the geomorphic stability assessment, existing scour protection measures, and the results of the hydraulic analyses. Therefore, scour depths adopted by VTAOT may differ from the computed values documented herein. 


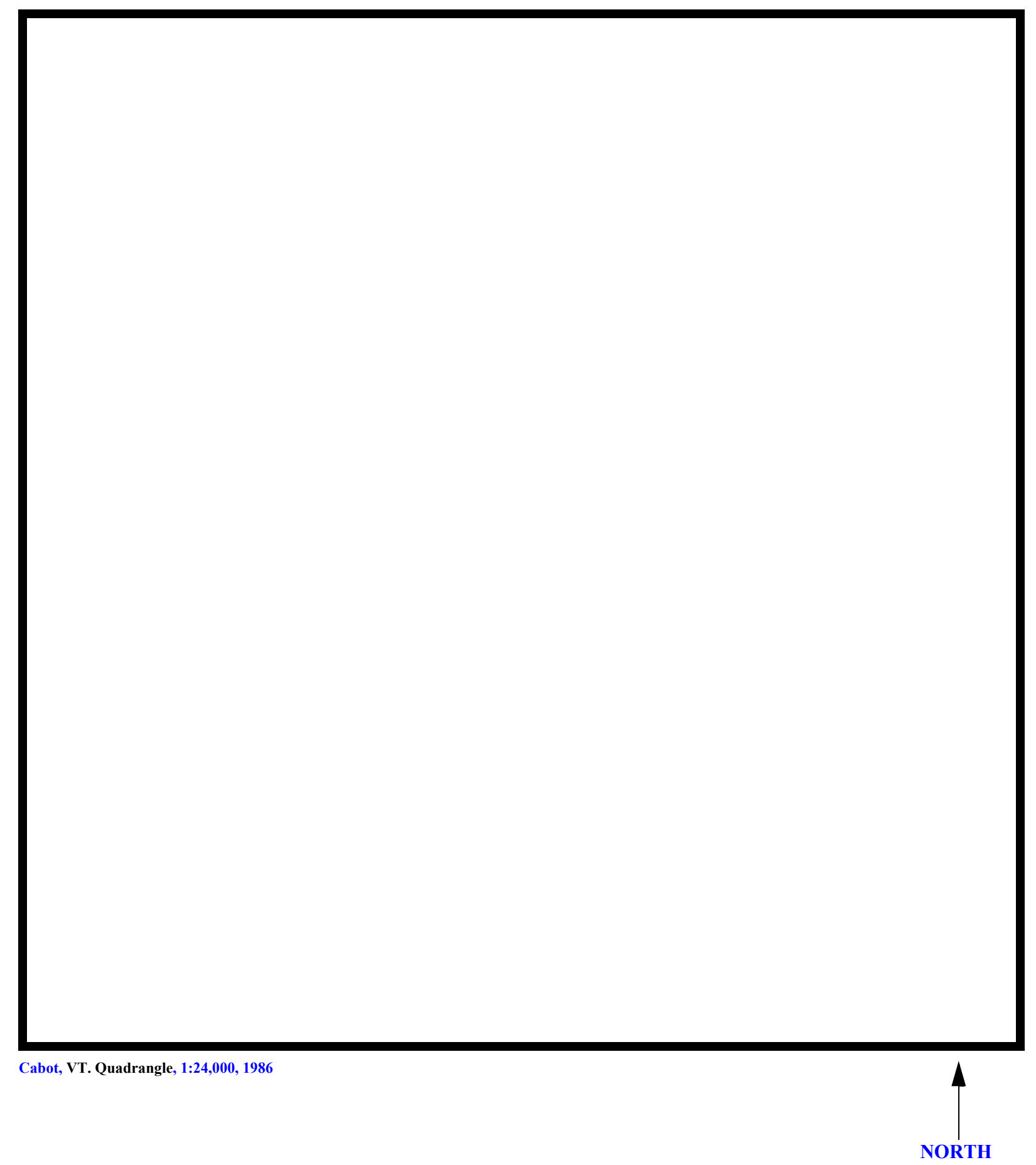

Figure 1. Location of study area on USGS 1:24,000 scale map. 
Figure 2. Location of study area on Vermont Agency of Transportation town highway map. 

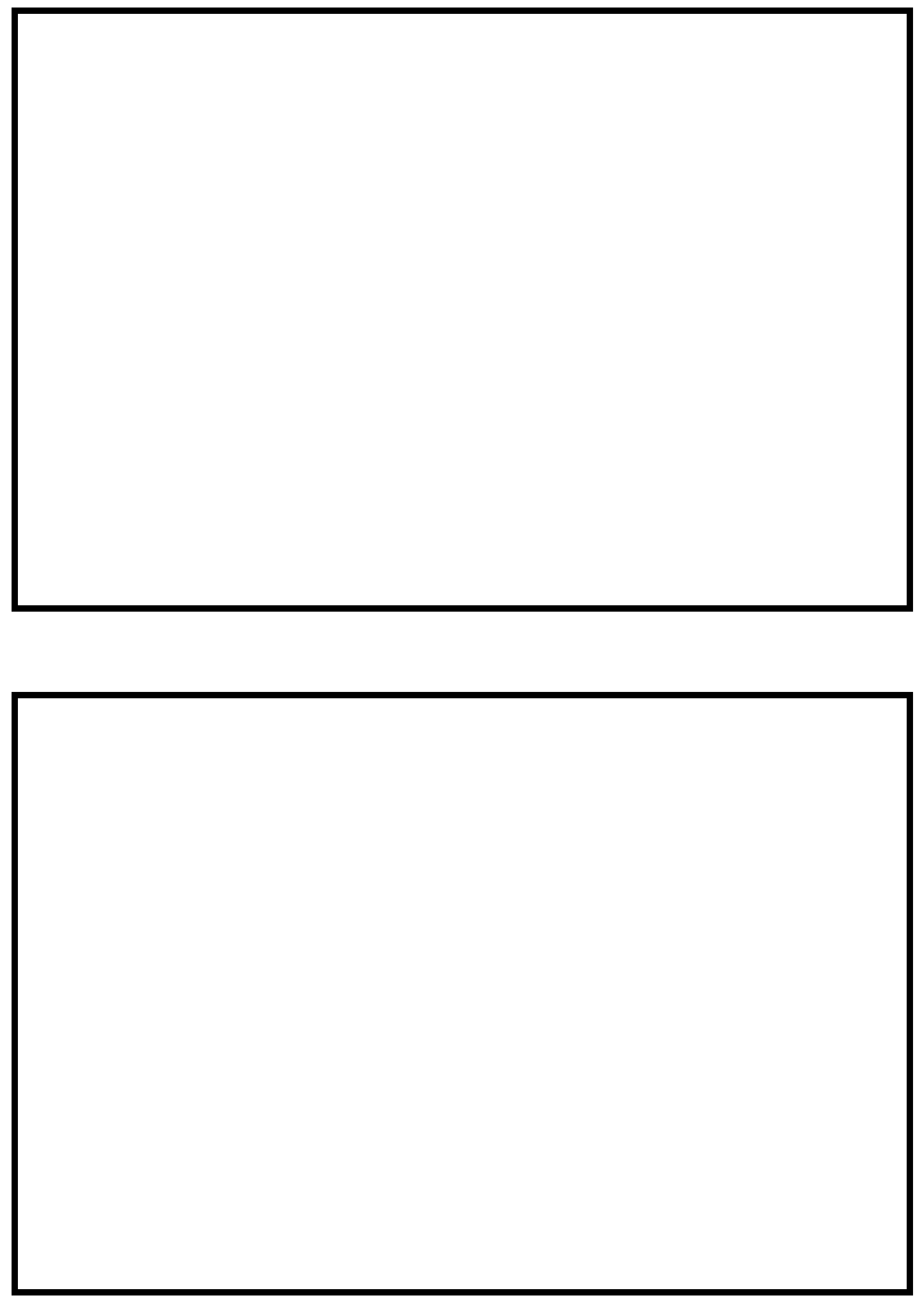

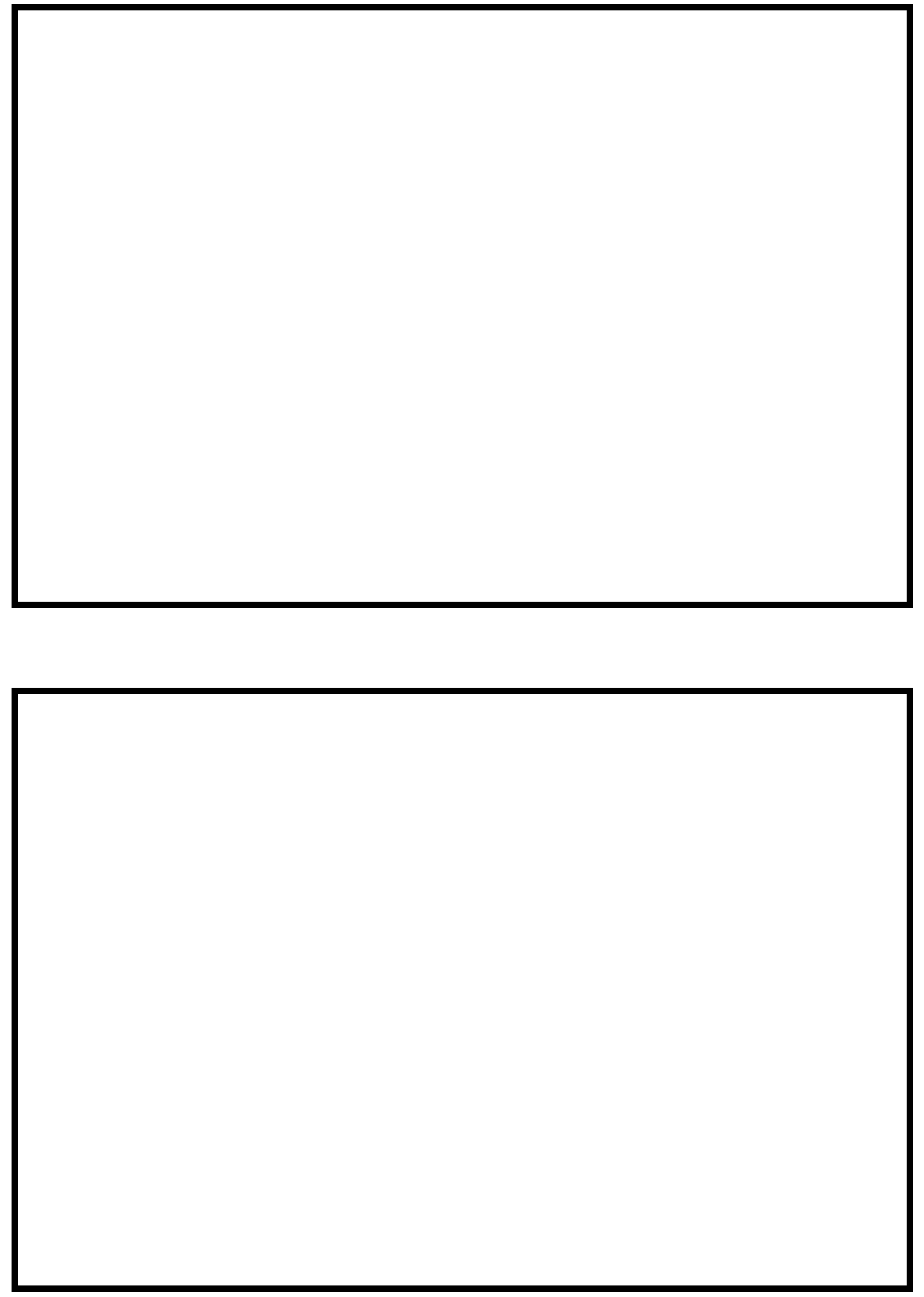


\section{LEVEL II SUMMARY}

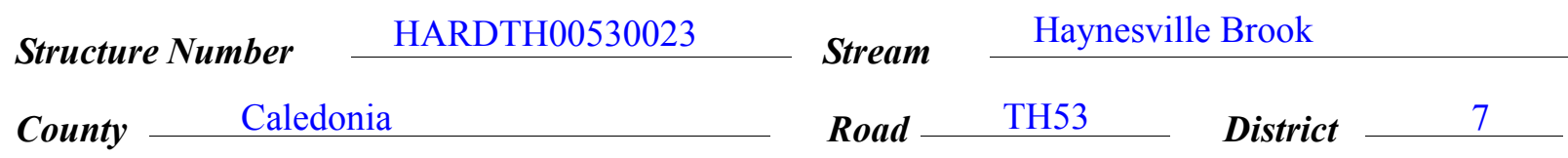

\section{Description of Bridge}

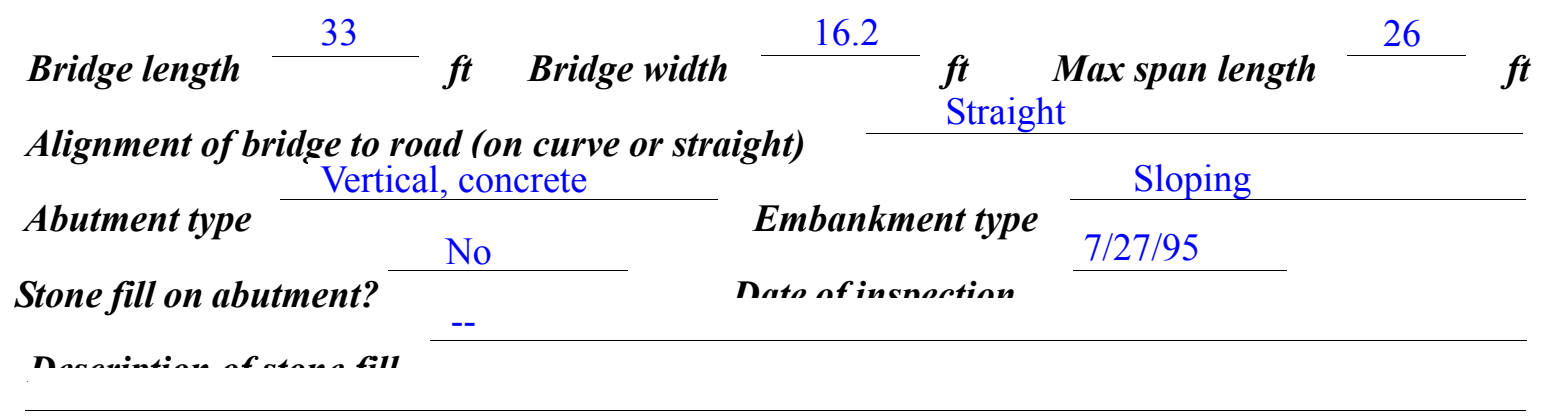

Abutments are concrete. The concrete may be facing of a stone abutment. Sheet piling has been driven around the abutments and filled with concrete and is acting as a subfooting.

Y 10

Is bridge skewed to flood flow according to $\mathrm{N} \quad$ r survey?
Angle

Debris accumulation on bridge at time of Level I or Level II site visit:

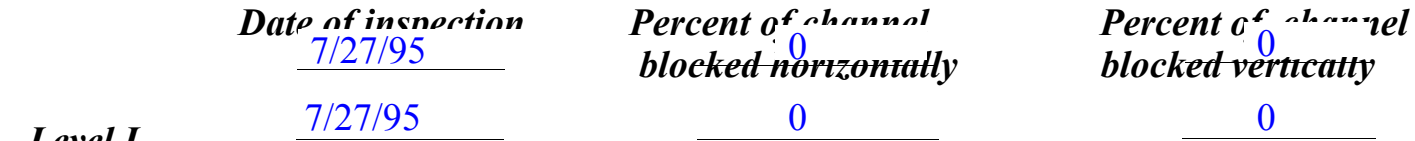

Level I $\quad$ High. The banks in the reach are unstable which may cause debris problems.

Potential for debris

There are two breached beaver dams downstream of the structure. July 27, 1995.

Dosrriho any, foaturos noar ar at tho hridoo that mav affort flow, (includo ahsorvation dato) 


\section{Description of the Geomorphic Setting}

General topography The channel is located within an upland moderate relief valley with

irregular flood plains.

Geomorphic conditions at bridge site: downstream (DS), upstream (US)

Date of inspection $\quad 7 / 27 / 95$

DS left: $\quad$ Irregular flood plain.

DS right: Irregular flood plain.

US left: Irregular flood plain.

US right: Irregular flood plain.

\section{Description of the Channel}

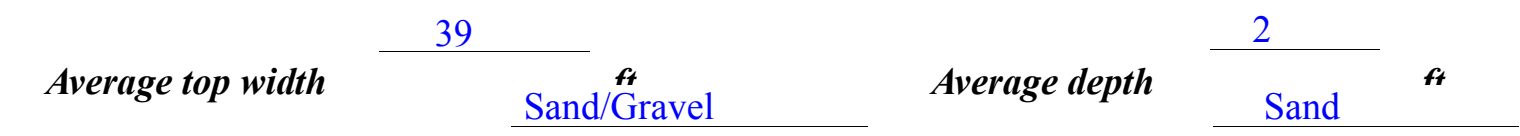

Predominant bed material

Bank material

Sinuous with alluvial

channel boundaries. Some anabranching occurring upstream of the bridge.

$\begin{array}{lllllll}7 / 27 / 95 \\ \text { Vegetative co }^{\text {Grass }} & \cdots & \ldots & \ldots & \ldots & .\end{array}$

DS left: $\quad$ Grass

DS right: $\quad$ Brush

US left: $\quad$ Grass

US right:

$\mathrm{N}$

Do banks appear stable? July 27, 1995. There is channel scour in the upstream and downstream reach as well as cut banks and point bars. There is an anabranch just upstream of the bridge and
date of observatton. the channel, in general, varies in width.

July 27,1995 . There are

the remains of two breached beaver dams downstream of the bridge. Several logs are lying in the Describe any obstructions in channel and date of observation.

upstream channel. 


\section{Hydrology}

Drainage area $\frac{14.2}{\boldsymbol{m i}^{2}}$

Percentage of drainage area in physiographic provinces: (approximate)

Physiographic province/section New England/New England Upland
Percent of drainage area 100

Is drainage area considered rural or urban? Rural Describe any significant urbanization:

Is there a USGS gage on the stream of interest?

No

USGS gage description

USGS gage number

Gage drainage area $\mathrm{mi}^{2}$

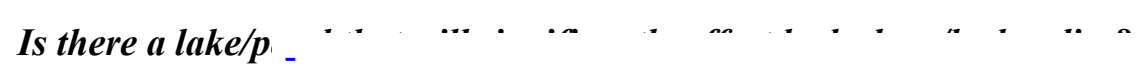

\section{Calculated Discharges $\underline{4,100}$ Q100 $\quad f t^{3} / \mathrm{s}$}

The 100- and 500-year discharges were selected

from a range defined by several empirical methods for determining flood discharges on a stream with basin characteristics such as this one (Benson, 1962; Johnson and Tasker, 1974; FHWA, 1983; Potter, 1957a\&b; Talbot, 1887). 


\section{Description of the Water-Surface Profile Model (WSPRO) Analysis}

Datum for WSPRO analysis (USGS survey, sea level, VTAOT plans)

USGS survey

Datum tie between USGS survey and VTAOT plans

None

Description of reference marks used to determine USGS datum. $\quad$ RM1 is a chiseled X on

top of the upstream, streamward corner of the left abutment (elev. $497.35 \mathrm{ft}$, arbitrary survey

datum). RM2 is a chiseled X on top of the downstream, streamward corner or the right

abutment (elev. $497.67 \mathrm{ft}$, arbitrary survey datum).

\section{Cross-Sections Used in WSPRO Analysis}

\begin{tabular}{|c|c|c|c|}
\hline${ }^{1}$ Cross-section & $\begin{array}{c}\text { Section } \\
\text { Reference } \\
\text { Distance } \\
\text { (SRD) in feet }\end{array}$ & $\begin{array}{c}{ }^{2} \text { Cross-section } \\
\text { development }\end{array}$ & Comments \\
\hline EXITX & -29 & 1 & Exit section \\
\hline FULLV & 0 & 2 & $\begin{array}{l}\text { Downstream Full-valley } \\
\text { section (Templated from } \\
\text { EXITX) }\end{array}$ \\
\hline BRIDG & 0 & 1 & Bridge section \\
\hline RDWAY & 10 & 1 & Road Grade section \\
\hline APPRO & 42 & 1 & Approach section \\
\hline
\end{tabular}

${ }^{1}$ For location of cross-sections see plan-view sketch included with Level I field form, Appendix E. For more detail on how cross-sections were developed see WSPRO input file. 


\section{Data and Assumptions Used in WSPRO Model}

Hydraulic analyses of the reach were done by use of the Federal Highway Administration's WSPRO step-backwater computer program (Shearman and others, 1986, and Shearman, 1990). The analyses reported herein reflect conditions existing at the site at the time of the study. Furthermore, in the development of the model it was necessary to assume no accumulation of debris or ice at the site. Results of the hydraulic model are presented in the Bridge Hydraulic Summary, Appendix B, and figure 7.

Channel roughness factors (Manning's “ $n$ ”) used in the hydraulic model were estimated using field inspections at each cross section following the general guidelines described by Arcement and Schneider (1989). Final adjustments to the values were made during the modelling of the reach. Channel " $n$ " values for the reach ranged from 0.035 to 0.040 , and overbank " $n$ " values ranged from 0.055 to 0.065 .

Normal depth at the exit section (EXITX) was assumed as the starting water surface. This depth was computed by use of the slope-conveyance method outlined in the user's manual for WSPRO (Shearman, 1990). The slope used was $0.0041 \mathrm{ft} / \mathrm{ft}$ which determined from surveyed thalweg points.

The approach section (APPRO) was surveyed approximately one bridge length upstream of the upstream face as recommended by Shearman and others (1986). This approach also provides a consistent method for determining scour variables. 


\section{Bridge Hydraulics Summary}

$\begin{array}{llll}\text { Average bridge embankment elevation } & 500.1 & f t \\ \text { Average low steel elevation } & 498.2 & \boldsymbol{f t}\end{array}$

100-year discharge $\quad 2,700 \quad \mathrm{ft}^{3} / \mathrm{s}$

Water-surface elevation in bridge opening $\quad 498.3 \quad f t$

Road overtopping? __ Y Discharge over road _ 1,170, s

\begin{tabular}{llc} 
Area of flow in bridge opening & $144 \quad \boldsymbol{f t}^{2}$ \\
\cline { 2 - 3 } Average velocity in bridge opening & $10.6 \quad \mathrm{ft} / \mathrm{s}$
\end{tabular}

Maximum WSPRO tube velocity at bridge $\quad 12.8 \mathrm{ft} / \mathrm{s}$

Water-surface elevation at Approach section with bridge 501.5

Water-surface elevation at Approach section without bridge $\quad \overline{498.8}$

Amount of backwater caused by bridge

$2.7 \quad i$

500-year discharge $\quad 4,100 \quad \boldsymbol{f t}^{3} / \mathrm{s}$

Water-surface elevation in bridge opening $\quad 498.3 \mathrm{ft}$

Road overtopping? ___ Y Discharge over road __ 2,620

Area of flow in bridge opening $\quad 144 \quad \mathrm{ft}^{2}$

Average velocity in bridge opening $10.5 \mathrm{ft} / \mathrm{s}$

Maximum WSPRO tube velocity at bridge 12.6 's

Water-surface elevation at Approach section with bridge 502.3

Water-surface elevation at Approach section without bridge $\quad 499.7$

Amount of backwater caused by bridge 2.6 .

Incipient overtopping discharge $\quad 1,140 \quad \mathrm{ft}^{3} / \mathrm{s}$

Water-surface elevation in bridge opening $498.3 \quad t$

\begin{tabular}{llll} 
Area of flow in bridge opening & $144 \quad \boldsymbol{f t}^{\mathbf{2}}$ & \\
\cline { 2 - 3 } Average velocity in bridge opening & $7.8 \quad \mathrm{ft} / \mathrm{s}$
\end{tabular}

Maximum WSPRO tube velocity at bridge $\quad 9.6 \mathrm{ft} / \mathrm{s}$

Water-surface elevation at Approach section with bridge

Water-surface elevation at Approach section without bridge

499.7

Amount of backwater caused by bridge $\quad 2.5$, t

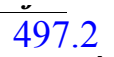




\section{Scour Analysis Summary}

\section{Special Conditions or Assumptions Made in Scour Analysis}

Scour depths were computed using the general guidelines described in Hydraulic Engineering Circular 18 (Richardson and others, 1995). Scour depths were calculated assuming an infinite depth of erosive material and a homogeneous particle-size distribution. The results of the scour analysis are presented in tables 1 and 2 and a graph of the scour depths is presented in figure 8 .

Contraction scour was computed by use of the Chang pressure-flow scour equation (Richardson and others, 1995, p. 145-146). For each of the modelled discharges, there was orifice flow at the bridge. Contraction scour at bridges with orifice flow is best estimated by use of the Chang pressure-flow scour equation (oral communication, J. Sterling Jones, October 4, 1996). The results of Laursen's clear-water contraction scour equation (Richardson and others, 1995, p. 32, equation 20) were also computed and can be found in appendix F.

Since less than five percent of the bed sample's distribution was coarser than the incipient motion size, armoring will not occur (U.S. Department of Transportation, 1993).

Abutment scour was computed by use of the HIRE equation (Richardson and others, 1995, p. 49, equation 29) because the HIRE equation is recommended when the length to depth ratio of the embankment blocking flow exceeds 25. Variables for the HIRE equation include the Froude number of the flow approaching the embankments, the length of the embankment blocking flow, and the depth of flow approaching the embankment less any roadway overtopping. 


\section{Scour Results}

\section{0-yr discharge 500-yr discharge}

Contraction scour:

(Scour depths in feet)

Main channel

Live-bed scour

Clear-water scour

Depth to armoring

Left overbank

Right overbank

Local scour:

Abutment scour

Left abutment

9.2

9.7

7.0

$12.3-$

12.9

$10.1-$

Right abutment

Pier scour

Pier 1

Pier 2

Pier 3

\section{Abutments:}

Left abutment

Right abutment

Piers:

Pier 1

Pier 2

overtopping discharge 


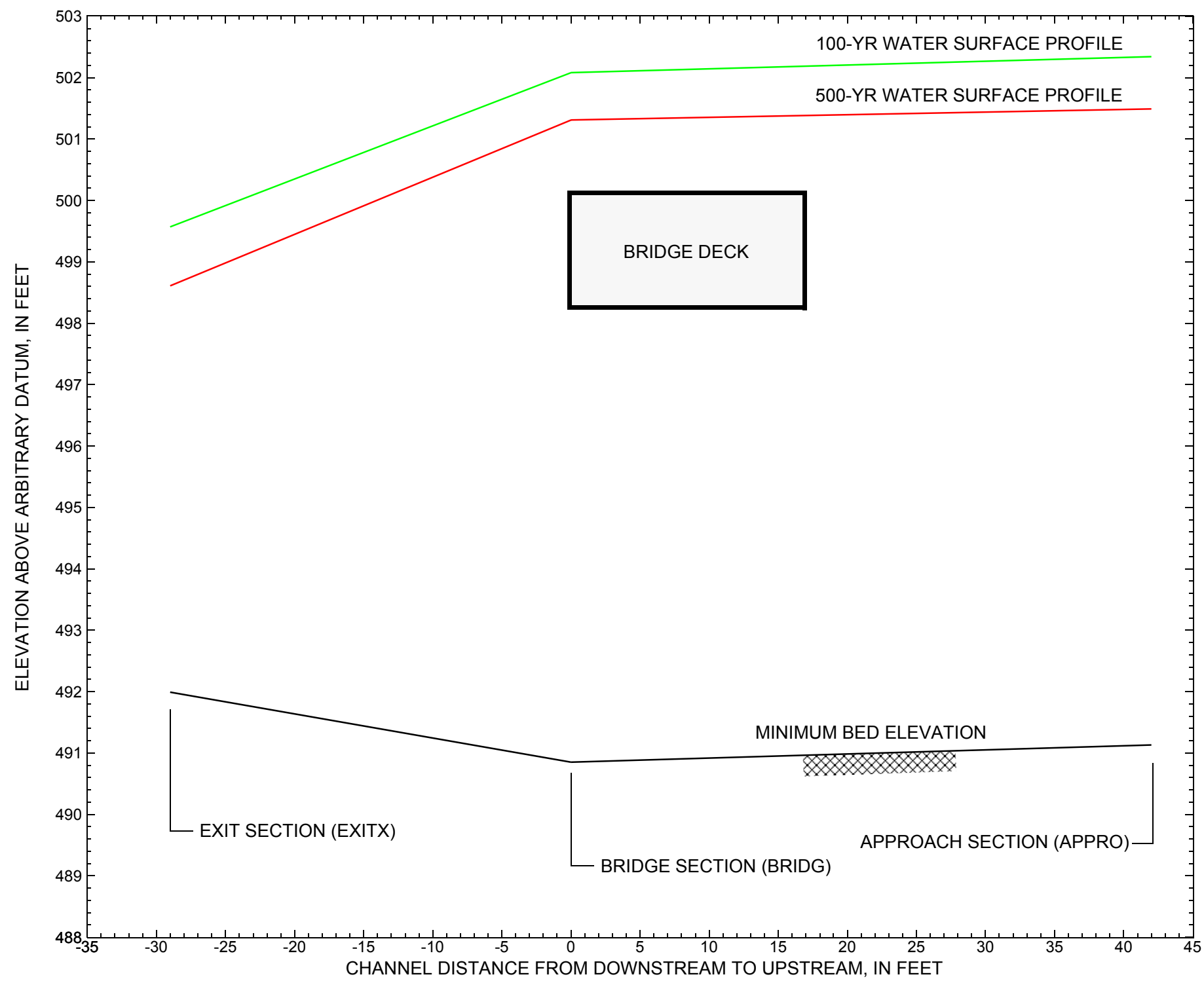

Figure 7. Water-surface profiles for the 100- and 500-yr discharges at structure HARDTH00530023 on Town Highway 53, crossing Haynesville Brook, Hardwick, Vermont. 


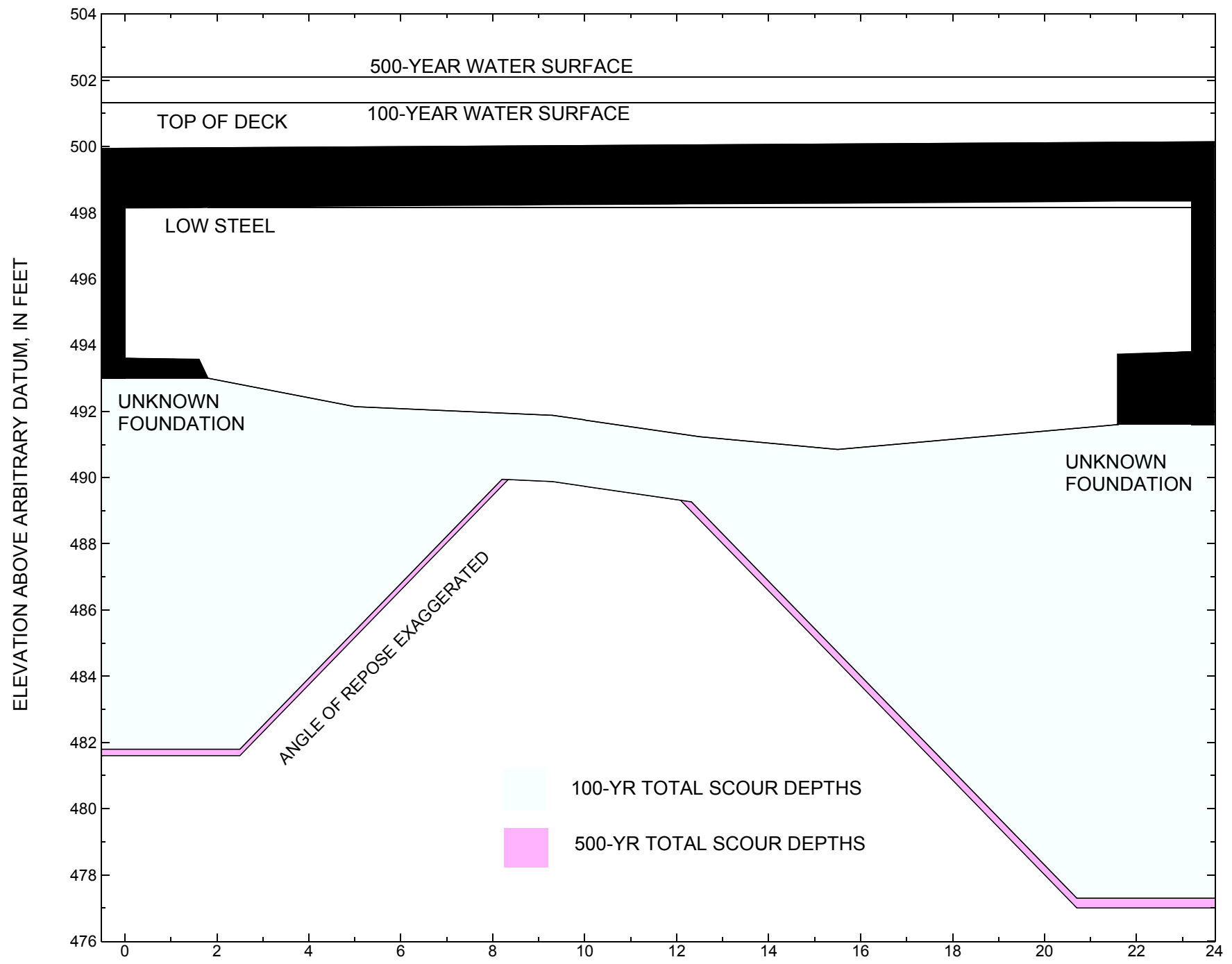

STATIONING FROM LEFT TO RIGHT ALONG BRIDGE SECTION, IN FEET

Figure 8. Scour elevations for the 100-yr and 500-yr discharges at structure HARDTH00530023 on Town Highway 53, crossing Haynesville Brook, Hardwick, Vermont. 
Table 1. Remaining footing/pile depth at abutments for the 100-year discharge at structure HARDTH00530023 on Town Highway 53, crossing Haynesville Brook, Hardwick, Vermont.

[VTAOT, Vermont Agency of Transportation; --,no data]

\begin{tabular}{|c|c|c|c|c|c|c|c|c|c|c|c|}
\hline Description & Station $^{\mathrm{a}}$ & $\begin{array}{l}\text { VTAOT } \\
\text { minimum } \\
\text { low-chord } \\
\text { elevation } \\
\text { (feet) }\end{array}$ & $\begin{array}{c}\text { Surveyed } \\
\text { minimum } \\
\text { low-chord } \\
\text { elevation } \\
\text { (feet) }\end{array}$ & $\begin{array}{c}\text { Bottom of } \\
\text { footing } \\
\text { elevation } \\
\text { (feet) }\end{array}$ & $\begin{array}{c}\text { Channel } \\
\text { elevation at } \\
\text { abutment/ } \\
\text { pier }^{2} \\
\text { (feet) }\end{array}$ & $\begin{array}{l}\text { Contraction } \\
\text { scour depth } \\
\text { (feet) }\end{array}$ & $\begin{array}{l}\text { Abutment } \\
\text { scour } \\
\text { depth } \\
\text { (feet) }\end{array}$ & $\begin{array}{l}\text { Pier } \\
\text { scour } \\
\text { depth } \\
\text { (feet) }\end{array}$ & $\begin{array}{l}\text { Depth of } \\
\text { total scour } \\
\text { (feet) }\end{array}$ & $\begin{array}{c}\text { Elevation of } \\
\text { scour }^{2} \\
\text { (feet) }\end{array}$ & $\begin{array}{c}\text { Remaining } \\
\text { footing/pile } \\
\text { depth } \\
\text { (feet) }\end{array}$ \\
\hline \multicolumn{12}{|c|}{100 -yr. discharge is 2,700 cubic-feet per second } \\
\hline Left abutment & 0.0 & -- & 498.14 & -- & 493.0 & 2.0 & 9.2 & -- & 11.2 & 481.8 & -- \\
\hline Right abutment & 23.2 & -- & 498.34 & -- & 491.6 & 2.0 & 12.3 & -- & 14.3 & 477.3 & -- \\
\hline
\end{tabular}

a.Measured along the face of the most constricting side of the bridge.

b.Arbitrary datum for this study.

Table 2. Remaining footing/pile depth at abutments for the 500-year discharge at structure HARDTH00530023 on Town Highway 53, crossing Haynesville Brook, Hardwick, Vermont.

[VTAOT, Vermont Agency of Transportation; --, no data]

\begin{tabular}{|c|c|c|c|c|c|c|c|c|c|c|c|}
\hline Description & Station $^{\mathrm{a}}$ & $\begin{array}{l}\text { VTAOT } \\
\text { minimum } \\
\text { low-chord } \\
\text { elevation } \\
\text { (feet) }\end{array}$ & $\begin{array}{c}\text { Surveyed } \\
\text { minimum } \\
\text { low-chord } \\
\text { elevation } \\
\text { (feet) }\end{array}$ & $\begin{array}{c}\text { Bottom of } \\
\text { footing } \\
\text { elevation } \\
\text { (feet) }\end{array}$ & $\begin{array}{c}\text { Channel } \\
\text { elevation at } \\
\text { abutment/ } \\
\text { pier }^{2} \\
\text { (feet) }\end{array}$ & $\begin{array}{l}\text { Contraction } \\
\text { scour depth } \\
\text { (feet) }\end{array}$ & $\begin{array}{l}\text { Abutment } \\
\text { scour } \\
\text { depth } \\
\text { (feet) }\end{array}$ & $\begin{array}{l}\text { Pier } \\
\text { scour } \\
\text { depth } \\
\text { (feet) }\end{array}$ & $\begin{array}{l}\text { Depth of } \\
\text { total scour } \\
\text { (feet) }\end{array}$ & $\begin{array}{c}\text { Elevation of } \\
\text { scour }^{2} \\
\text { (feet) }\end{array}$ & $\begin{array}{c}\text { Remaining } \\
\text { footing/pile } \\
\text { depth } \\
\text { (feet) }\end{array}$ \\
\hline \multicolumn{12}{|c|}{500 -yr. discharge is 4,100 cubic-feet per second } \\
\hline Left abutment & 0.0 & -- & 498.14 & -- & 493.0 & 1.7 & 9.7 & -- & 11.4 & 481.6 & -- \\
\hline Right abutment & 23.2 & -- & 498.34 & -- & 491.6 & 1.7 & 12.9 & -- & 14.6 & 477.0 & -- \\
\hline
\end{tabular}

a.Measured along the face of the most constricting side of the bridge.

b.Arbitrary datum for this study. 


\section{SELECTED REFERENCES}

Arcement, G.J., Jr., and Schneider, V.R., 1989, Guide for selecting Manning's roughness coefficients for natural channels and flood plains: U.S. Geological Survey Water-Supply Paper 2339, 38 p.

Barnes, H.H., Jr., 1967, Roughness characteristics of natural channels: U.S. Geological Survey Water-Supply Paper 1849,213 p.

Benson, M. A., 1962, Factors Influencing the Occurrence of Floods in a Humid Region of Diverse Terrain: U.S. Geological Survey WaterSupply Paper 1580-B, 64 p.

Brown, S.A. and Clyde, E.S., 1989, Design of riprap revetment: Federal Highway Administration Hydraulic Engineering Circular No. 11, Publication FHWA-IP-89-016, 156 p.

Federal Highway Administration, 1983, Runoff estimates for small watersheds and development of sound design: Federal Highway Administration Report FHWA-RD-77-158

Froehlich, D.C., 1989, Local scour at bridge abutments in Ports, M.A., ed., Hydraulic Engineering--Proceedings of the 1989 National Conference on Hydraulic Engineering: New York, American Society of Civil Engineers, p. 13-18.

Hayes, D.C.,1993, Site selection and collection of bridge-scour data in Delaware, Maryland, and Virginia: U.S. Geological Survey WaterResources Investigation Report 93-4017, 23 p.

Johnson, C.G. and Tasker, G.D.,1974, Progress report on flood magnitude and frequency of Vermont streams: U.S. Geological Survey OpenFile Report 74-130, 37 p.

Lagasse, P.F., Schall, J.D., Johnson, F., Richardson, E.V., Chang, F., 1995, Stream Stability at Highway Structures: Federal Highway Administration Hydraulic Engineering Circular No. 20, Publication FHWA-IP-90-014, 144 p.

Laursen, E.M., 1960, Scour at bridge crossings: Journal of the Hydraulics Division, American Society of Civil Engineers, v. 86, no. HY2, p. 39-53.

Potter, W. D., 1957a, Peak rates of runoff in the Adirondack, White Mountains, and Maine woods area, Bureau of Public Roads

Potter, W. D., 1957b, Peak rates of runoff in the New England Hill and Lowland area, Bureau of Public Roads

Richardson, E.V. and Davis, S.R., 1995, Evaluating scour at bridges: Federal Highway Administration Hydraulic Engineering Circular No. 18, Publication FHWA-IP-90-017, 204 p.

Richardson, E.V., Simons, D.B., and Julien, P.Y., 1990, Highways in the river environment: Federal Highway Administration Publication FHWA-HI-90-016.

Ritter, D.F., 1984, Process Geomorphology: W.C. Brown Co., Debuque, Iowa, 603 p.

Shearman, J.O., 1990, User's manual for WSPRO--a computer model for water surface profile computations: Federal Highway Administration Publication FHWA-IP-89-027, 187 p.

Shearman, J.O., Kirby, W.H., Schneider, V.R., and Flippo, H.N., 1986, Bridge waterways analysis model; research report: Federal Highway Administration Publication FHWA-RD-86-108, 112 p.

Talbot, A.N., 1887, The determination of water-way for bridges and culverts.

U.S. Department of Transportation, 1993, Stream stability and scour at highway bridges, Participant Workbook: Federal Highway Administration Publication FHWA HI-91-011.

U.S. Geological Survey, 1986, Cabot, Vermont 7.5 Minute Series quadrangle map: U.S. Geological Survey Topographic Maps, Scale $1: 24,000$. 
APPENDIX A:

\section{WSPRO INPUT FILE}




\section{WSPRO INPUT FILE}

GR

GR

GR

GR

GR

$\mathrm{N}$

SA

$\mathrm{XS}$

$B R$

GR

GR

GR

GR

$\mathrm{N}$

CD

*

$\mathrm{XR}$

GR

GR

GR

GR

GR

*

AS

GR

GR

GR

GR

GR

$\mathrm{N}$

SA

\section{*}

HP 1 BRIDG

HP 2 BRIDG

HP 2 RDWAY

HP 1 APPRO

HP 2 APPRO

*

HP 1 BRIDG

HP 2 BRIDG

HP 2 RDWAY

HP 1 APPRO

HP 2 APPRO
U.S. GEOLOGICAL SURVEY WSPRO INPUT FILE hard023.wsp CREATED ON 11-AUG-95 FOR BRIDGE HARDTH00530023 USING FILE hard023.dca HYDRAULIC ANALYSIS OF HARD023 SAO

$62930 \quad 552553551516 \quad 17 \quad 13 \quad 3 * \begin{array}{llllllllll}15 & 14 & 23 & 21 & 11 & 12 & 4 & 7 & 3\end{array}$

$27004100 \quad 1140$

0.00410 .00410 .0041

EXITX -29

$-179.5,507.27$

\begin{tabular}{l}
$.27-173.7,503.17$ \\
\hline
\end{tabular}

$-64.8,496.78$

$-143.0,504.61$

$-109.4,503.06$

$0.0,492.85$

$-40.0,495.87$

$-7.5,496.16$

$4.5,492.63$

$10.4,492.26$

$16.1,492.20$

$20.9,491.99$

$27.1,492.05$

$30.8,492.87$

$41.0,495.49$

$60.7,497.23$

$110.8,497.19$

$224.7,503.49$

$286.6,507.59$

0.055

0.040

0.055

$\begin{array}{ll}-7.5 & 41.0\end{array}$

0

$\begin{array}{lll}0 & 498.24 & 10.0\end{array}$

$0.0,498.14 \quad 0.1,493.60$

$5.0,492.14 \quad 9.3,491.88$

$1.6,493.56$

$1.8,492.95$

$12.5,491.23$

$15.5,490.85$

$19.0,491.29$

$21.6,491.57$

$21.6,493.71$

$23.1,493.79$

$23.2,498.34$

$0.0,498.14$

0.035

120.3

$\begin{array}{llll}\text { RDWAY } & 10 & 16.2 & 2\end{array}$

$-148.5,505.03-144.4,504.15$

$-108.2,503.08-75.5,501.23$

$-4.0,499.98-3.9,500.39$

$-138.7,504.71$

$-125.0,504.39$

$-53.8,500.31$

$-18.1,500.02$

$29.2,500.53$

$29.2,499.92$

$74.6,499.70$

$109.2,499.95$

$175.5,501.49$

$229.6,504.40$

$274.1,507.97$

$341.9,510.16$

$364.6,517.79$

$$
42
$$

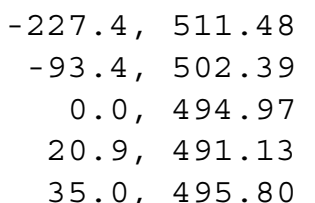

$-218.6, \quad 509.27$

$-169.9,506.49$

$-135.4,504.58$

$-66.6,498.99$

$-32.3,498.28$

$-18.2,496.21$

$11.0,491.36$

$16.5,491.80$

$29.9,492.06$

$32.9,492.80$

$25.2,491.62$

$132.4,497.05$

$221.7,503.75$
0.065

0

0.039

42.5
$498.34 \quad 1498.34$

$498.34 * * 1523$

501.31 * * 1169

501.491501 .49

$501.49 * * 2700$

498.341498 .34

498.34 * 1502

$502.08 * * 2619$

502.341502 .34

502.34 * 4100 


\section{APPENDIX B: \\ WSPRO OUTPUT FILE}




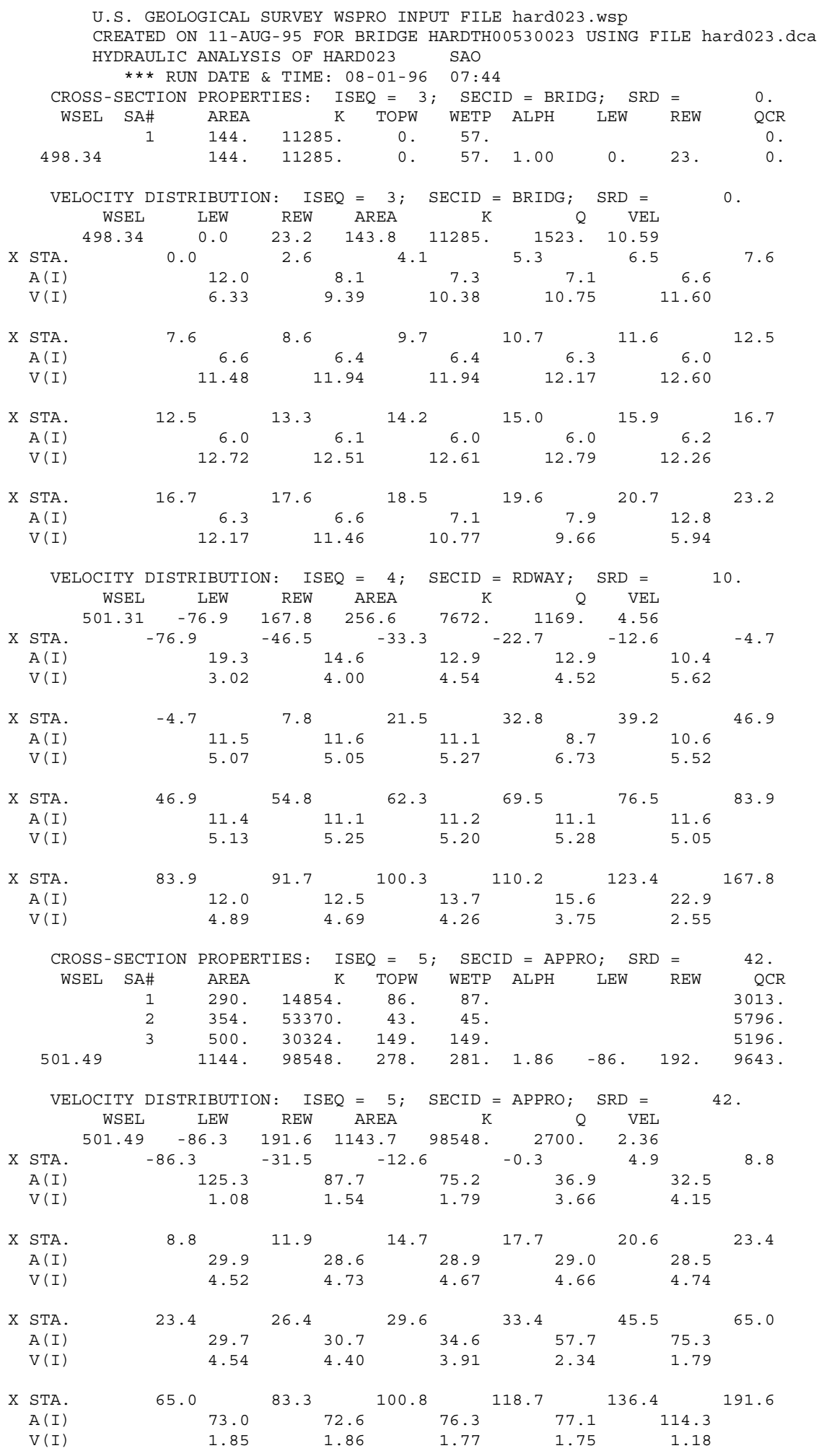


WSPRO OUTPUT FILE (continued)

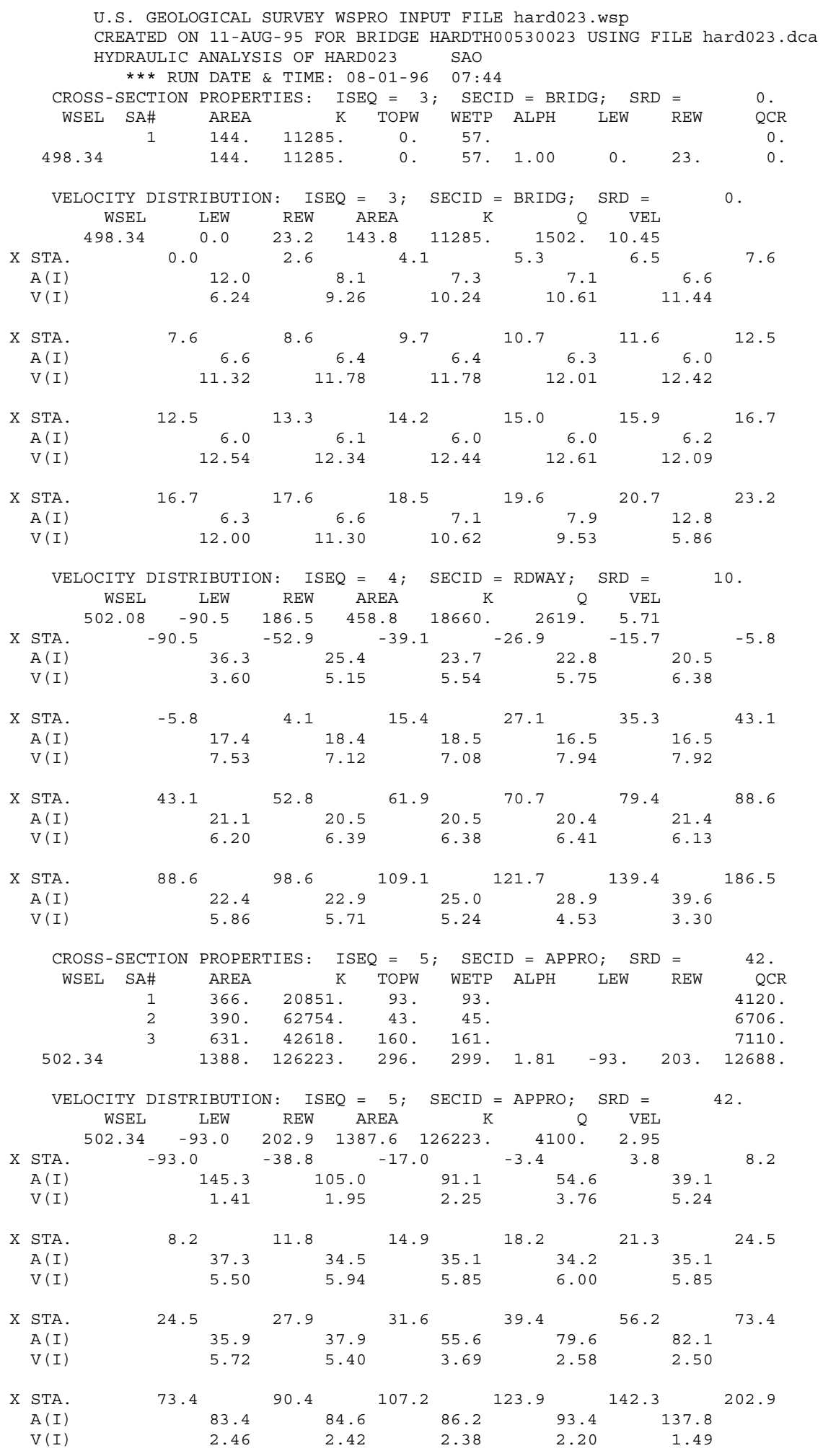


WSPRO OUTPUT FILE (continued)

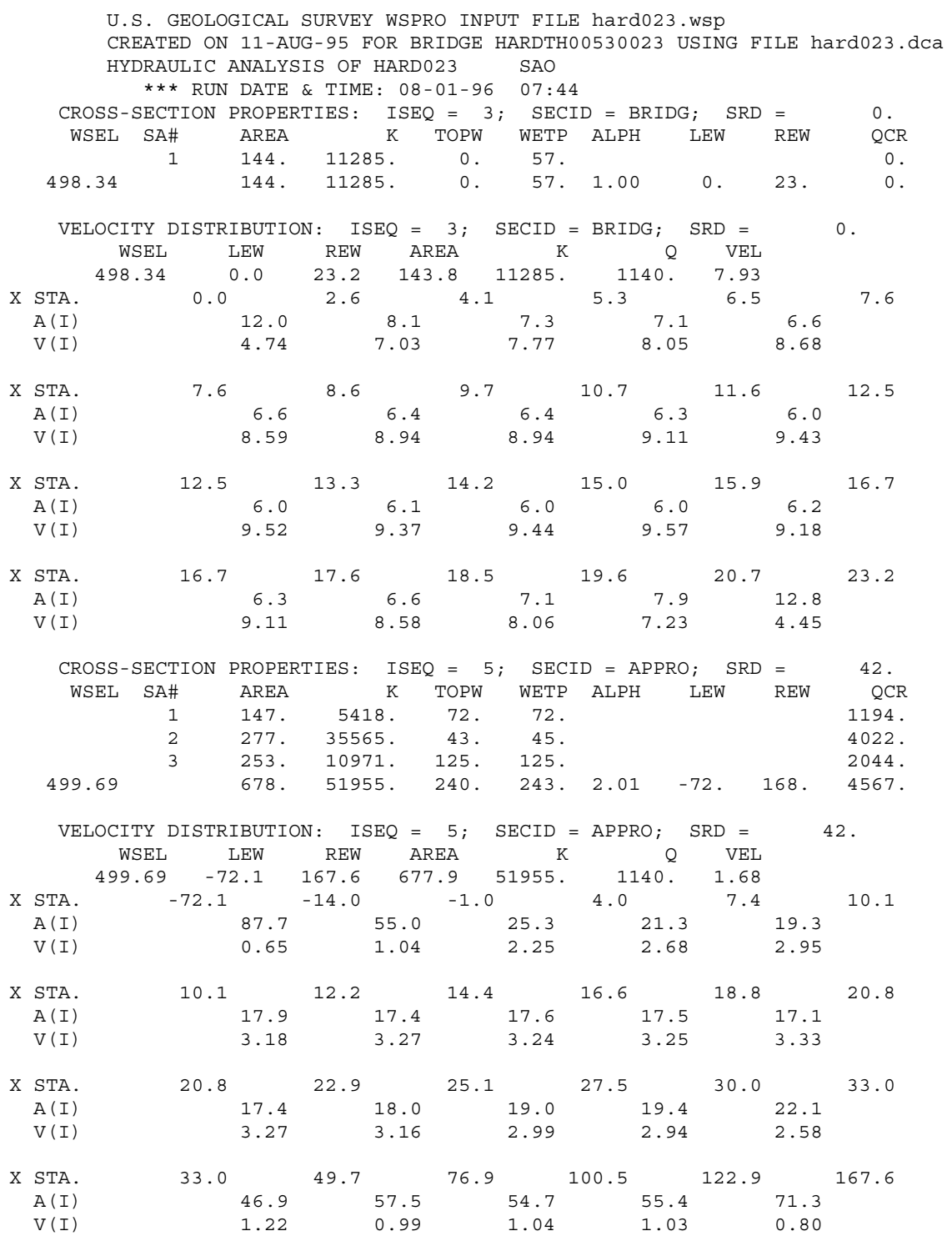


WSPRO OUTPUT FILE (continued)

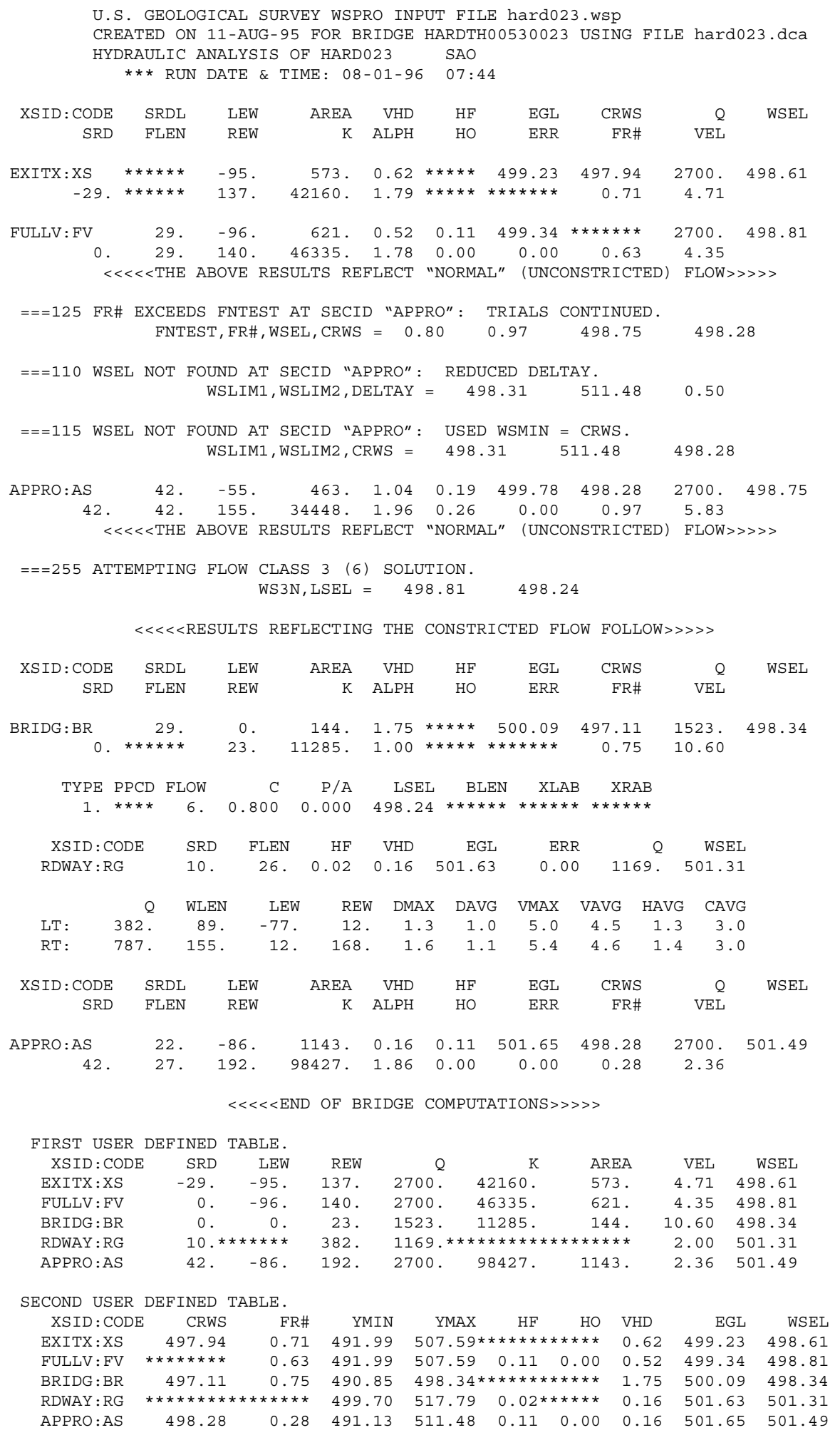


WSPRO OUTPUT FILE (continued)

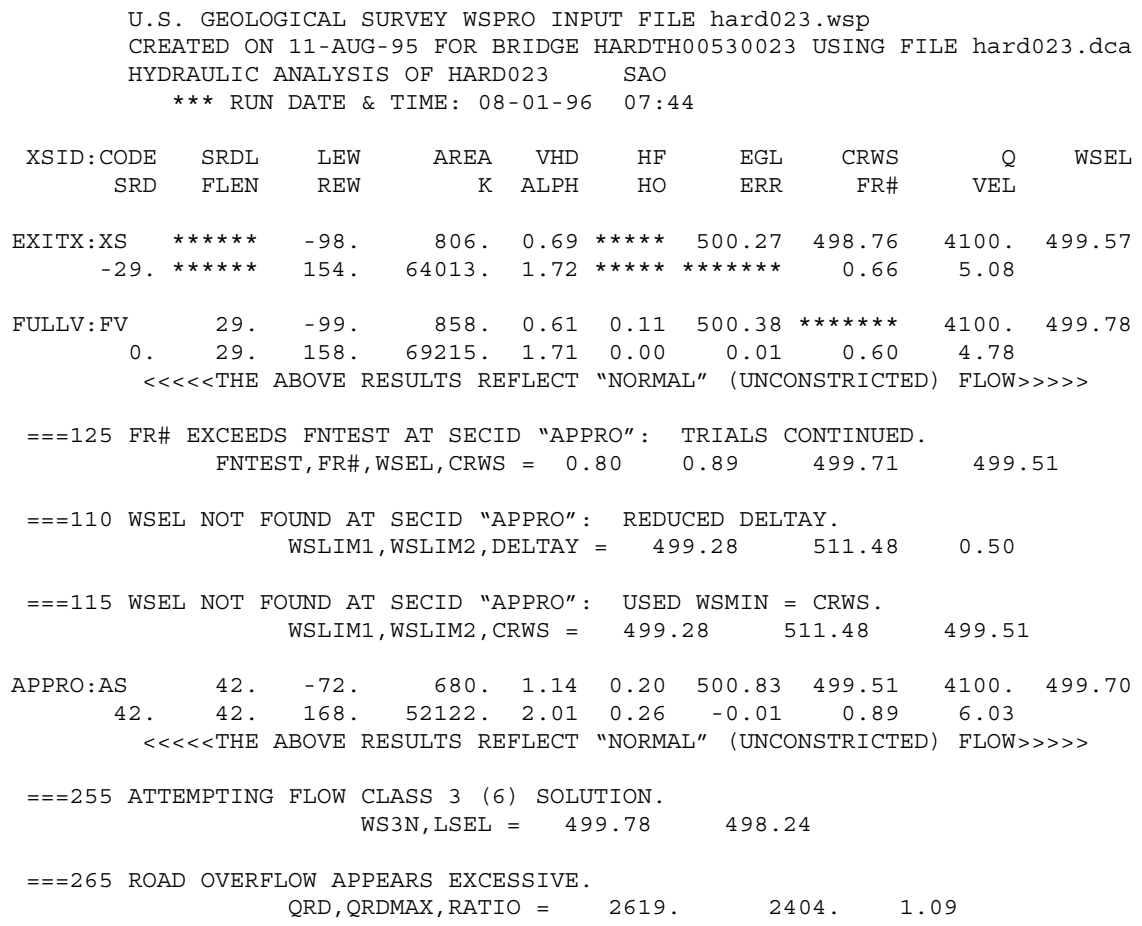


WSPRO OUTPUT FILE (continued)

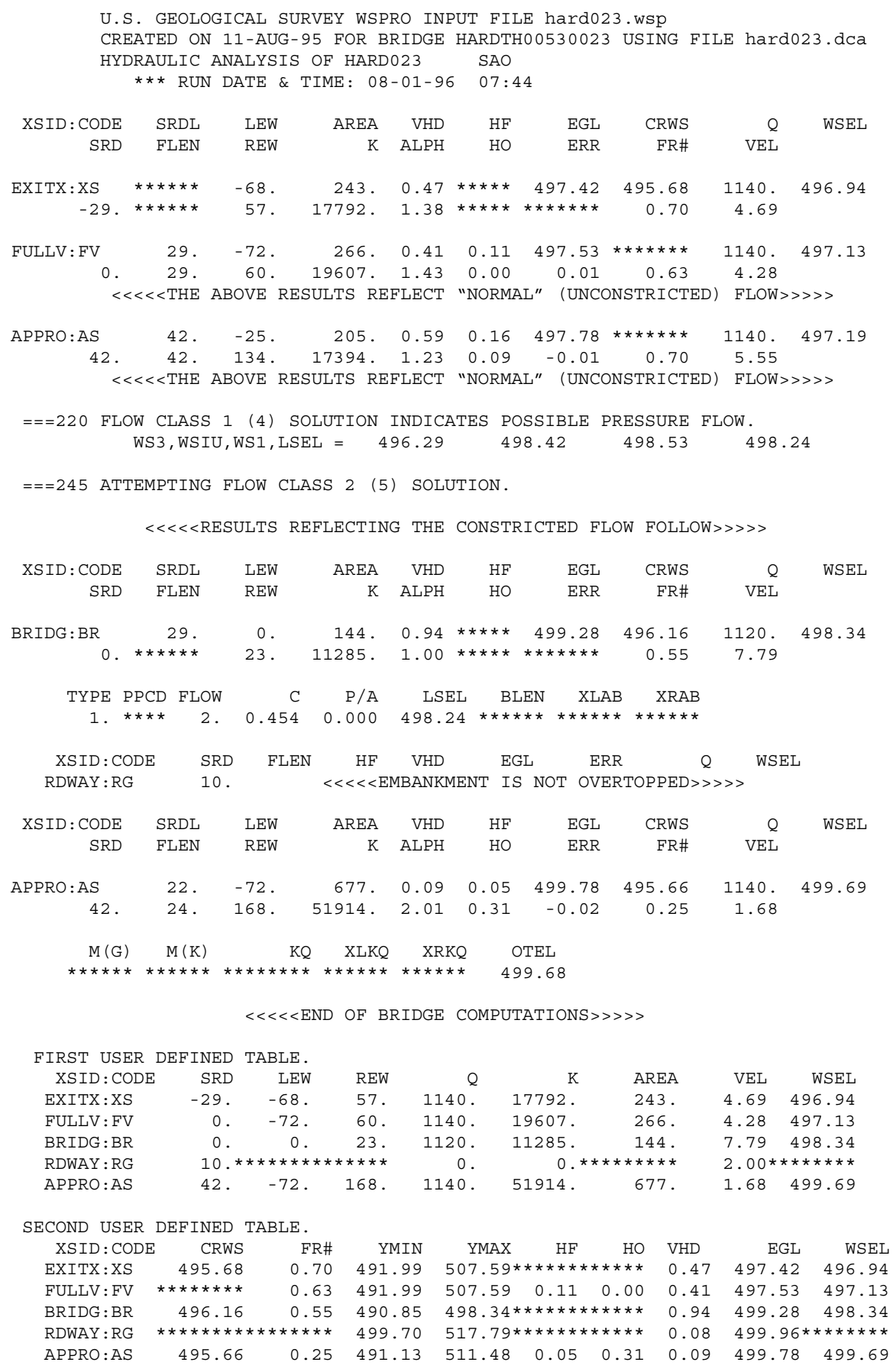




\section{APPENDIX C:}

\section{BED-MATERIAL PARTICAL-SIZE DISTRIBUTION}




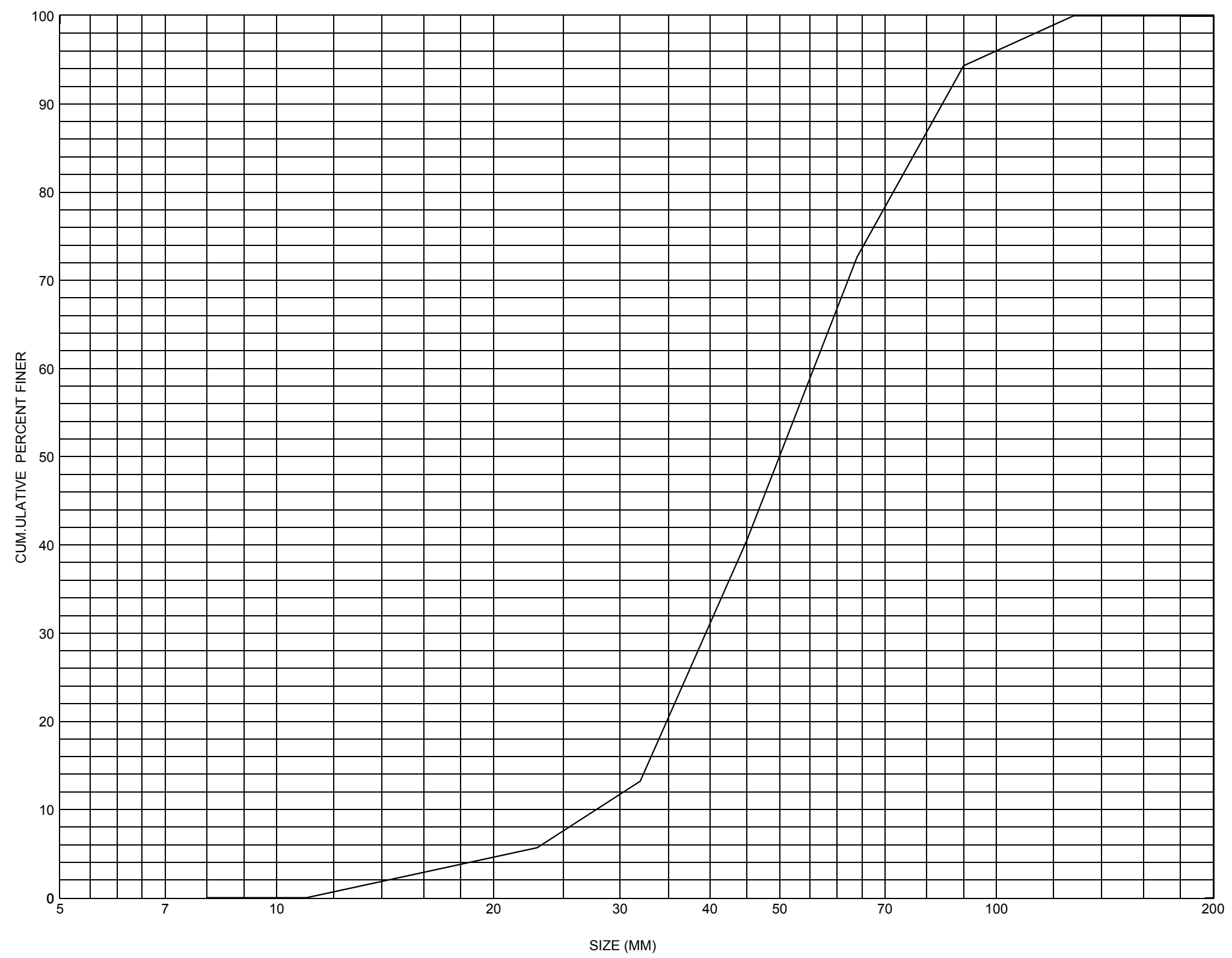

Appendix C. Bed material particle-size distribution for one pebble count transect in the channel approach of structure HARDTH00530023, in Hardwick, Vermont. 


\section{APPENDIX D: \\ HISTORICAL DATA FORM}




\section{Structure Number HARDTH00530023}

\section{General Location Descriptive}

Data collected by (First Initial, Full last name) $\mathbf{E}$. BOEHMLER

Date $(M M / D D / Y Y) \_\mathbf{0 3} / \underline{24} / \underline{95}$

Highway District Number (I - 2; nn) $\mathbf{0 7}$

Town (FIPS place code; I - 4; nnnnn) $\mathbf{3 1 8 2 5}$

Waterway (I - 6) HAYNESVILLE BROOK

Route Number $\mathbf{T H 0 5 3}$

Topographic Map Cabot

Latitude (I - 16; nnnn.n) $\mathbf{4 4 2 9 6}$
County (FIPS county code; I - 3; nnn)

Mile marker (I - 11; nnn.nnn) $\mathbf{0 0 0 0 0 0}$

Road Name (I - 7): -

Vicinity (I - 9) AT JCT TH 53 + VT 15

Hydrologic Unit Code: $\mathbf{0 2 0 1 0 0 0 5}$

Longitude (i - 17; nnnnn.n) 72191

\section{Select Federal Inventory Codes}

FHWA Structure Number (I - 8) $\mathbf{1 0 0 3 0 5 0 0 2 3 0 3 0 5}$

Maintenance responsibility $(I-21 ; n n)$

Year built (I - 27; YYYY) 1954

Average daily traffic, ADT (I - 29; nnnnnn) $\underline{000010}$

Year of ADT (I - 30; YY) $\mathbf{9 3}$

Opening skew to Roadway $(I-34 ; n n) \quad \mathbf{0 0}$

Operational status $(I-41 ; X)$ A

Structure type (I - 43; nnn) $\mathbf{3 0 2}$

Approach span structure type $(I-44 ; n n n) \quad \mathbf{0 0 0}$

Number of spans (I - 45; nnn) $\mathbf{0 0 1}$

Number of approach spans (I - 46; nnnn) $\mathbf{0 0 0 0}$

Comments:

The structural inspection report of 6/1/93 indicates the structure is a steel stringer type bridge with a timber deck. Abutments and wingwalls are grouted "laid up" stone blocks with some stone chinking and concrete facing. Large areas of grouting have broken or spalled out. Some of the stone chinking is also missing. An eight foot section at the downstream end of the right abutment is undermined 2-3 feet with a penetration of 3-12 inches. The greatest penetration is noted at the abutment end. A couple 2.5-3 foot deep scour holes are in the channel near the downstream end of the left and right abutments. Some erosion can be seen along the up- and downstream banks from past flooding. (Continued, page 33) 


\section{Bridge Hydrologic Data}

Is there hydrologic data available? $\underline{\mathbf{N}}$ if No, type ctrl-n $h \quad$ VTAOT Drainage area $\left(m i^{2}\right)$ : -

Terrain character:

Stream character \& type: -

Streambed material:

Discharge Data (cfs):

$$
\begin{aligned}
& Q_{2.33}- \\
& Q_{50}-
\end{aligned}
$$

Record flood date $(M M / D D / Y Y)$ :

Estimated Discharge (cfs): Ice conditions (Heavy, Moderate, Light) : -

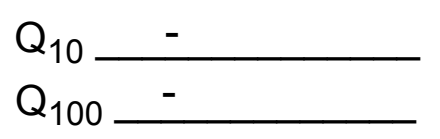

$$
\begin{aligned}
& Q_{25}- \\
& Q_{500}-
\end{aligned}
$$

Water surface elevation $(f t):-$

The stage increases to maximum highwater elevation (Rapidly, Not rapidly):

The stream response is (Flashy, Not flashy):

Describe any significant site conditions upstream or downstream that may influence the stream's stage: -

Watershed storage area (in percent): _ _ \%

The watershed storage area is: - (1-mainly at the headwaters; 2- uniformly distributed; 3-immediatly upstream oi the site)

Water Surface Elevation Estimates for Existing Structure:

\begin{tabular}{|l|l|l|l|l|l|}
\hline Peak discharge frequency & $Q_{2.33}$ & $Q_{10}$ & $Q_{25}$ & $Q_{50}$ & $Q_{100}$ \\
Water surface elevation (ft)) & - & - & - & - & - \\
Velocity (ft/sec) & - & - & - & - & - \\
\hline
\end{tabular}

Long term stream bed changes: -

Is the roadway overtopped below the $\mathrm{Q}_{100}$ ? (Yes, No, Unknown): $\mathbf{U}$ Frequency: Relief Elevation (ft): Discharge over roadway at $Q_{100}\left(f^{3} / \mathrm{sec}\right)$ :

Are there other structures nearby? (Yes, No, Unknown): Upstream distance (miles): Town: If No or Unknown, type ctrl-n os Highway No. : Structure No. : Year Built:

Clear span (ft): Clear Height $(f t)$ : Full Waterway $\left(f^{2}\right)$ : 
Downstream distance (miles): Town: Year Built:

Highway No. : Structure No. : Structure Type:

Clear span $(f t):$ Clear Height $(f t)$ : Full Waterway $\left(f^{2}\right)$ :

Comments:

Some possible settlement has been noted over the years. Minor gravel point bars are reported. There are beaver dams noted downstream. Not much stone fill protection is noted. Comments were made to repair the $8 \mathrm{ft}$. undermined section and the scour holes at both abutments in the report.

(Evidently, repairs were made before the 7/27/95 Level I assessment.)

\section{USGS Watershed Data}

Watershed Hydrographic Data

Drainage area (DA) $14.23 \mathrm{mi}^{2}$

Watershed storage (ST) .67

Bridge site elevation 961

Main channel length 6.8 $\mathrm{ft}$ $\%$

$10 \%$ channel length elevation $\mathbf{1 0 0 1}$ $\mathrm{ft} \quad 85 \%$ channel length elevation

1933

Main channel slope $(S)$ 182.88 $\mathrm{ft} / \mathrm{mi}$

Watershed Precipitation Data

Average site precipitation in Average headwater precipitation in

Maximum 2yr-24hr precipitation event $(124,2)$ in

Average seasonal snowfall (Sn) $\mathrm{ft}$ 


\section{Bridge Plan Data}

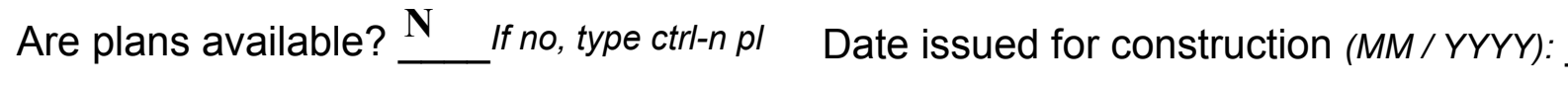

Project Number

Minimum channel bed elevation:

Low superstructure elevation: USLAB DSLAB USRAB DSRAB Benchmark location description:

NO BENCHMARK INFORMATION

Reference Point (MSL, Arbitrary, Other): Datum (NAD27, NAD83, Other):

Foundation Type: 4

If 1: Footing Thickness

If 2: Pile Type: (1-Wood; 2-Steel or metal; 3-Concrete)

If 3 : Footing bottom elevation:

Is boring information available? $\mathbf{N}$ If no, type ctrl-n bi Number of borings taken:

Foundation Material Type: $\mathbf{3}$ (1-regolith, 2-bedrock, 3-unknown)

Briefly describe material at foundation bottom elevation or around piles:

NO FOUNDATION MATERIAL INFORMATION

Comments:

NO PLANS. 


\section{Cross-sectional Data}

Is cross-sectional data available? $\mathbf{N}$ If no, type ctrl-n xs

Source (FEMA, VTAOT, Other)? -

Comments: NO CROSS SECTION INFORMATION

\begin{tabular}{|l|l|l|l|l|l|l|l|l|l|l|l|}
\hline Station & - & - & - & - & - & - & - & - & - & - & - \\
\hline Feature & - & - & - & - & - & - & - & - & - & - & - \\
\hline $\begin{array}{l}\text { Low cord } \\
\text { elevation }\end{array}$ & - & - & - & - & - & - & - & - & - & - & - \\
\hline $\begin{array}{l}\text { Bed } \\
\text { elevation }\end{array}$ & - & - & - & - & - & - & - & - & - & - & - \\
\hline $\begin{array}{l}\text { Low cord to } \\
\text { bed length }\end{array}$ & - & - & - & - & - & - & - & - & - & - & - \\
\hline Station & - & - & - & - & - & - & - & - & - & - & - \\
\hline Feature & - & - & - & - & - & - & - & - & - & - & - \\
\hline $\begin{array}{l}\text { Low cord } \\
\text { elevation }\end{array}$ & - & - & - & - & - & - & - & - & - & - & - \\
\hline $\begin{array}{l}\text { Bed } \\
\text { elevation }\end{array}$ & - & - & - & - & - & - & - & - & - & - & - \\
\hline $\begin{array}{l}\text { Low cord to } \\
\text { bed length }\end{array}$ & - & - & - & - & - & - & - & - & - & - & - \\
\hline
\end{tabular}

Source (FEMA, VTAOT, Other)?

Comments: NO CROSS SECTION INFORMATION

\begin{tabular}{|l|l|l|l|l|l|l|l|l|l|l|l|}
\hline Station & - & - & - & - & - & - & - & - & - & - & - \\
\hline Feature & - & - & - & - & - & - & - & - & - & - & - \\
\hline $\begin{array}{l}\text { Low cord } \\
\text { elevation }\end{array}$ & - & - & - & - & - & - & - & - & - & - & - \\
\hline $\begin{array}{l}\text { Bed } \\
\text { elevation }\end{array}$ & - & - & - & - & - & - & - & - & - & - & - \\
\hline $\begin{array}{l}\text { Low cord to } \\
\text { bed length }\end{array}$ & - & - & - & - & - & - & - & - & - & - & - \\
\hline Station & - & - & - & - & - & - & - & - & - & - & - \\
\hline Feature & - & - & - & - & - & - & - & - & - & - & - \\
\hline $\begin{array}{l}\text { Low cord } \\
\text { elevation }\end{array}$ & - & - & - & - & - & - & - & - & - & - & - \\
\hline $\begin{array}{l}\text { Bed } \\
\text { elevation }\end{array}$ & - & - & - & - & - & - & - & - & - & - & - \\
\hline $\begin{array}{l}\text { Low cord to } \\
\text { bed length }\end{array}$ & - & - & - & - & - & - & - & - & - & - & - \\
\hline
\end{tabular}




\section{APPENDIX E: \\ LEVEL I DATA FORM}


U. S. Geological Survey

Bridge Field Data Collection and Processing Form

Qa/Qc Check by: EW

Date: $\mathbf{0 4 / 1 1 / 9 6}$

\section{A. General Location Descriptive}

1. Data collected by (First Initial, Full last name) L. MEDALIE

2. Highway District Number $\mathbf{0 7}$

County CALENDONIA

Waterway (I - 6) HAYNESVILLE BROOK

Route Number TH 53

3. Descriptive comments:

AT JUNCTION BETWEEN TOWN HIGHWAY 53 AND VT 15.
Mile marker 0000000

Town HARDWICK 31825

Road Name -

Hydrologic Unit Code: $\mathbf{0 2 0 1 0 0 0 5}$

Date $(M M / D D / Y Y) \underline{\mathbf{0 7}} / \underline{\mathbf{2 7}} / \underline{1995}$

\section{B. Bridge Deck Observations}

\section{Surface cover... $\quad$ LBUS $5 \quad$ RBUS $4 \quad$ LBDS $4 \quad$ RBDS 4 Overall 4}

(2b us,ds,lb,rb: 1- Urban; 2- Suburban; 3- Row crops; 4- Pasture; 5- Shrub- and brushland; 6- Forest; 7- Wetland)

5. Ambient water surface...US $\underline{1}$ UB 1 DS 1 (1-pool; 2- riffle)

6. Bridge structure type 1 (1- single span; 2- multiple span; 3- single arch; 4- multiple arch; 5- cylindrical culvert; 6- box culvert; or 7- other)
7. Bridge length $\mathbf{3 3}$
(feet)
Span length $\mathbf{2 6}$
(feet)
Bridge width 16.2 (feet)

\section{Road approach to bridge:}
8. LB 0
RB 0
( 0 even, 1- lower, 2- higher)
9. LB_2
RB $\underline{2}$
(1- Paved, 2- Not paved)

10. Embankment slope (run / rise in feet / foot):

US left

\begin{tabular}{|c|c|c|c|}
\hline \multicolumn{2}{|c|}{ Protection } & \multirow{2}{*}{ 13.Erosion } & \multirow{2}{*}{ 14.Severity } \\
\hline 11.Type & 12.Cond. & & \\
\hline
\end{tabular}

LBUS

RBUS

RBDS

LBDS

\begin{tabular}{l|l|l}
\hline 2 & $\frac{2}{2}$ \\
\hline 2 & $\frac{2}{2}$ & 2 \\
\hline
\end{tabular}

\begin{tabular}{l}
\hline $\mathbf{0}$ \\
\hline $\mathbf{0}$ \\
\hline $\mathbf{0}$ \\
\hline
\end{tabular}

Bank protection types: 0- none; 1- < 12 inches;

2- < 36 inches; 3- < 48 inches;

4- $<60$ inches; 5- wall / artificial levee

Bank protection conditions: 1- good; 2- slumped;

3- eroded; 4- failed

Erosion: 0 - none; 1- channel erosion; 2-

road wash; 3- both; 4- other

Erosion Severity: 0 - none; 1- slight; 2- moderate; 3- severe

\section{Channel approach to bridge (BF):}

15. Angle of approach: $\mathbf{0}$

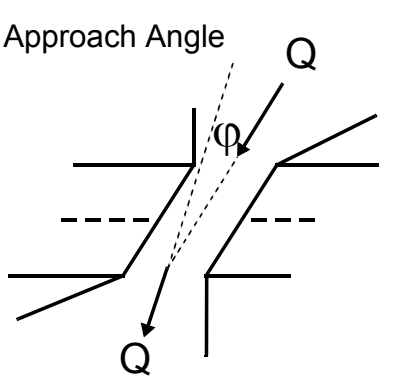

16. Bridge skew: 10

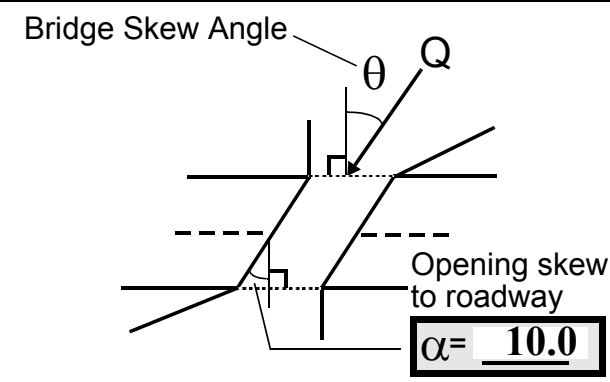

17. Channel impact zone 1 :

Where? LB $(L B, R B)$

Exist? $\mathbf{Y}(Y$ or $N)$

Range? 38 feet US

Severity 1

Channel impact zone 2:

Where? RB (LB, RB)

Exist? $\mathbf{Y}(Y$ or $N)$

Range? 15 feet $\underline{\mathbf{U S}}$ (US, UB, DS) to $\underline{14}$ feet $\underline{\mathrm{DS}}$

Impact Severity: 0- none to very slight; 1- Slight; 2- Moderate; 3- Severe 
18. Bridge Type: $\mathbf{1 b}$

1a- Vertical abutments with wingwalls

$1 \mathrm{~b}$ - Vertical abutments without wingwalls

2- Vertical abutments and wingwalls, sloping embankment

Wingwalls perpendicular to abut. face

3- Spill through abutments

4- Sloping embankment, vertical wingwalls and abutments

Wingwall angle less than $90^{\circ}$.

19. Bridge Deck Comments (surface cover variations, measured bridge and span lengths, bridge type variations,

approach overflow width, etc.)

\#7: values from VTAOT; measured values: bridge length $=33$ feet; bridge span $=23$ feet; bridge width $=16.2$

feet

\#8: RB road approach is even with bridge for 30 feet, then the road rises.

\#11-12: Protection is composed of granite blocks, probably of the previous abutment, slightly slumped at all four corners.

\section{Upstream Channel Assessment}

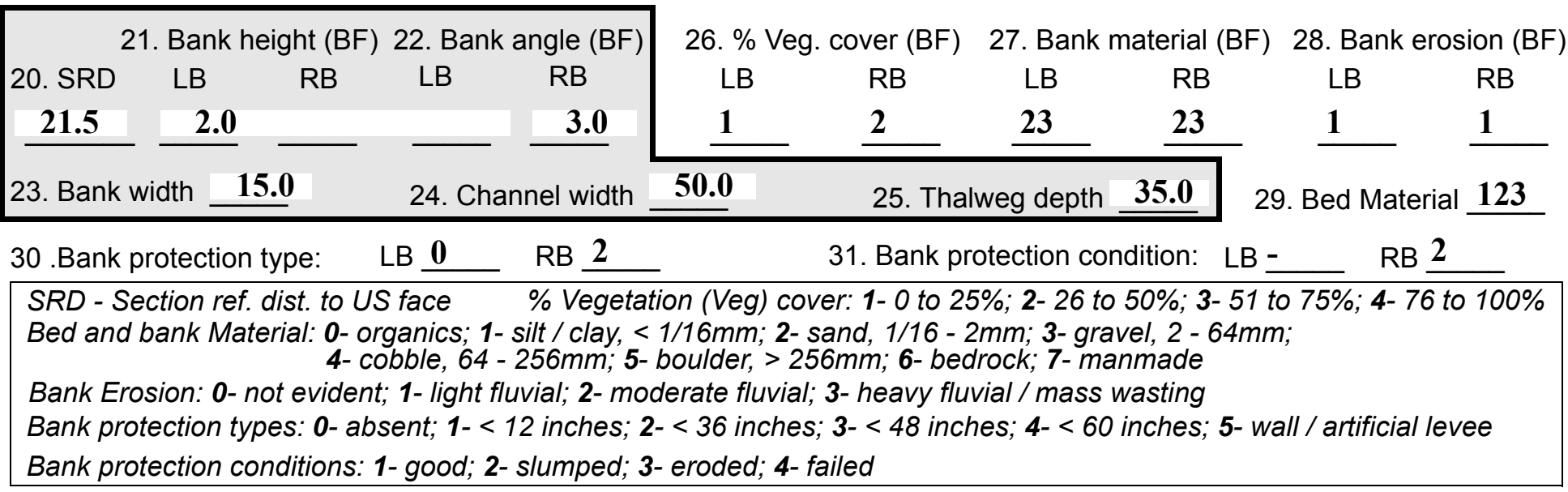

32. Comments (bank material variation, minor inflows, protection extent, etc.):

\#26: Vegetation cover on $R B$ is comprised of three trees within one bridge length.

\#30: Right bank protection is from $10 \mathrm{ft}$. to $30 \mathrm{ft}$. US. 
33.Point/Side bar present? Y

$(Y$ or $N$. if $N$ type ctrl-n pb) 34 . Mid-bar distance: 92

35. Mid-bar width: 27

36. Point bar extent: $\mathbf{5 4}$ feet US

(US, UB) to 122 feet $\underline{\mathbf{U S}}$ (US, UB, L

BS, positioned $\underline{25}$ $\%$ LB to $\underline{85} \%$ RB

37. Material: 324

38. Point or side bar comments (Circle Point or Side; Note additional bars, material variation, status, etc.):

39. Is a cut-bank present? $\mathbf{Y}$ (Yor if $N$ type ctrl-n cb)

41. Mid-bank distance: $\mathbf{9 5}$

43. Bank damage: 1

42. Cut bank extent: 38

40. Where? $\underline{\mathbf{L B}}$ (LB or RB)

feet $\underline{\mathbf{U S}}$ (US, UB) to $\underline{\mathbf{1 4 0}}$ feet $\underline{\mathbf{U S}}$ (US, UB, DS)

(1- eroded and/or creep; 2- slip failure; 3- block failure)

44. Cut bank comments (eg. additional cut banks, protection condition, etc.):

Another cut-bank present on RB from 17 feet US to 0 feet US. Bank is eroded and tree roots are exposed.

45. Is channel scour present? $\mathbf{Y}$ ( $Y$ or if $N$ type ctrl-n cs) $\quad$ 46. Mid-scour distance: 16

47. Scour dimensions: Length $\underline{\mathbf{3 5}}$ Width $\underline{8}$ Depth: $\underline{\mathbf{1 . 7 5}}$ Position $\underline{\mathbf{5 5}} \%$ LB to $\underline{\mathbf{8 5}} \% \mathrm{RB}$

48. Scour comments (eg. additional scour areas, local scouring process, etc.):

49. Are there major confluences? $\mathbf{N}$

51. Confluence 1: Distance Confluence 2: Distance -
52. Enters on -

Enters on -
( $Y$ or if $N$ type ctrl-n $m c$ ) ( $L B$ or $R B)$ (LB or $R B)$

54. Confluence comments (eg. confluence name):

NO MAJOR CONFLUENCES

Minor confluence on LB at 23 feet US from bridge (width $=4$ feet; height $=5$ feet). Currently it is dry.

\section{Under Bridge Channel Assessment}

55. Channel restraint (BF)? LB 2 (1- natural bank; 2- abutment; 3- artificial levee)

\begin{tabular}{|cccc|cccc}
\multicolumn{2}{c}{ 56. Height (BF) } & \multicolumn{2}{c}{57 Angle (BF) } & \multicolumn{2}{c}{ 61. Material (BF) } & \multicolumn{2}{c}{ 62. Erosion (BF) } \\
LB & RB & LB & RB & LB & RB & LB & RB \\
$\mathbf{2 5 . 5}$ & & & $\mathbf{1 . 5}$ & & & &
\end{tabular}

58. Bank width (BF) -

59. Channel width (Amb) -

60. Thalweg depth $(\mathrm{Amb}) \quad \mathbf{9 0 . 0}$

63. Bed Material -

Bed and bank Material: 0- organics; 1- silt / clay, < 1/16mm; 2- sand, 1/16 - 2mm; 3- gravel, 2 - 64mm; 4- cobble, 64 - 256mm; 5- boulder, > 256mm; 6- bedrock; 7- manmade

Bank Erosion: 0- not evident; 1- light fluvial; 2- moderate fluvial; 3- heavy fluvial / mass wasting

64. Comments (bank material variation, minor inflows, protection extent, etc.):

213

\#63: The bed material is gravel and sand in the middle of the channel, whereas sand and silt constitute the bed material up to five feet adjacent to both abutments. 
65. Debris and Ice Is there debris accumulation?

67. Debris Potential $\underline{1}$ (1- Low; 2- Moderate; 3- High)

69. Is there evidence of ice build-up? 1

70. Debris and Ice Comments:

1

A few logs and twigs in stream.
$(Y$ or $N)$ 66. Where? $\mathbf{Y}$

68. Capture Efficiency 3

(1- Upstream; 2- At bridge; 3- Both)

Ice Blockage Potential $\mathbf{N}$
(1-Low; 2-Moderate; 3- High)

(1-Low; 2-Moderate; 3- High)

\begin{tabular}{|l|c|c|c|c|c|c|c|c|}
\hline Abutments & $\begin{array}{c}\text { 71. Attack } \\
\angle \text { (BF) }\end{array}$ & $\begin{array}{c}72 \text {. Slope } \angle \\
\text { (Qmax) }\end{array}$ & $\begin{array}{c}\text { 73. Toe } \\
\text { loc. (BF) }\end{array}$ & $\begin{array}{c}\text { 74. Scour } \\
\text { Condition }\end{array}$ & $\begin{array}{c}75 . \text { Scour } \\
\text { depth }\end{array}$ & $\begin{array}{c}\text { 76. Exposure } \\
\text { depth }\end{array}$ & 77. Material & 78. Length \\
\hline LABUT & & $\mathbf{0}$ & $\mathbf{9 0}$ & $\mathbf{0}$ & $\mathbf{2}$ & $\mathbf{1 . 6}$ & $\mathbf{2 . 8}$ & $\mathbf{9 0 . 0}$ \\
\hline RABUT & $\mathbf{1}$ & $\mathbf{1 0}$ & $\mathbf{9 0}$ & & & $\mathbf{0}$ & $\mathbf{2}$ & $\mathbf{2 3 . 0}$ \\
\hline
\end{tabular}

Pushed: $L B$ or RB

Toe Location (Loc.): 0- even, 1- set back, 2- protrudes

Scour cond.: 0- not evident; 1- evident (comment); 2- footing exposed; 3-undermined footing; 4- piling exposed; 5- settled; 6- failed

Materials: 1- Concrete; 2- Stone masonry or drywall; 3- steel or metal; 4- wood

79. Abutment comments (eg. undermined penetration, unusual scour processes, debris, etc.):

0.9

2.1

1

\#76: LABUT - maximum of 2.8 feet at DS end.

RABUT - maximum of 2.1 feet at US end.

80. Wingwalls:

Exist? Material? Scour Scour Exposure Angle? Length? Condition? depth? depth?

USLWW:

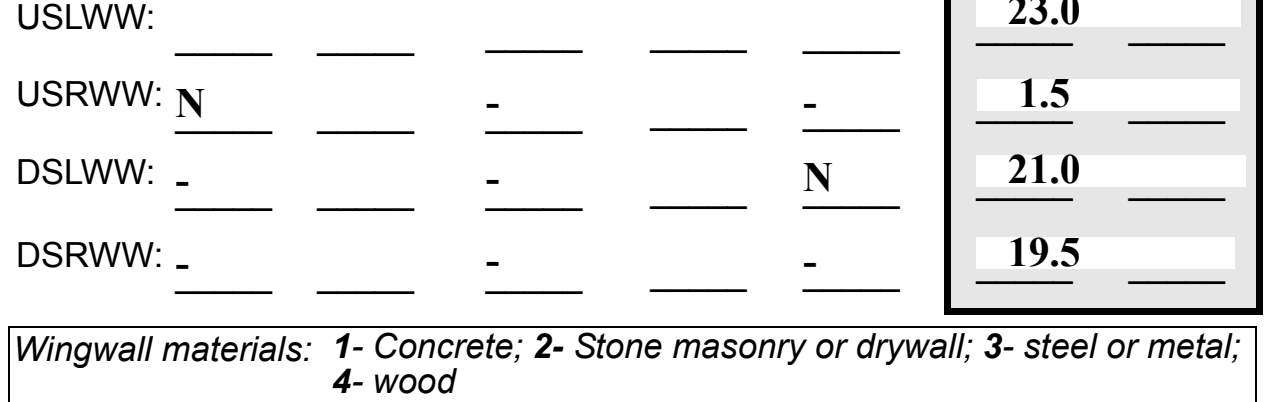

Wingwall materials: 1- Concrete; 2- Stone masonry or drywall; 3- steel or metal; 4- wood

23.0

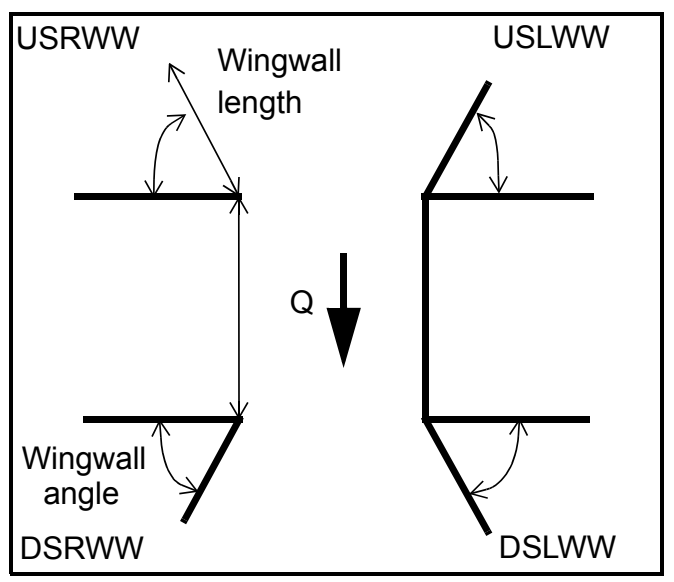

82. Bank / Bridge Protection:

\begin{tabular}{|l|l|l|l|l|l|l|l|l|}
\hline Location & USLWW & USRWW & LABUT & RABUT & LB & RB & DSLWW & DSRWW \\
\hline Type & - & - & N & - & - & - & - & - \\
\hline Condition & N & - & - & - & - & - & - & - \\
\hline Extent & - & - & - & - & - & - & - & - \\
\hline
\end{tabular}

Bank / Bridge protection types: 0- absent; 1- < 12 inches; 2- < 36 inches; 3- < 48 inches; 4- < 60 inches; 
83. Wingwall and protection comments (eg. undermined penetration, unusual scour processes, etc.):

-
-
-
-
-
-
-
-

\section{Piers:}

84. Are there piers? (Y or if $N$ type ctrl-n pr)

\begin{tabular}{|l|l|l|l|l|l|l|l|}
\hline \multirow{2}{*}{$\begin{array}{l}85 . \\
\text { Pier no. }\end{array}$} & \multicolumn{3}{|c|}{ width (w) feet } & \multicolumn{3}{c|}{ elevation (e) feet } \\
\cline { 2 - 9 } & w1 & w2 & w3 & e@w1 & e@w2 & e@w3 \\
\hline Pier 1 & - & - & - & - & - & - \\
\hline Pier 2 & - & - & - & - & - & - \\
\hline Pier 3 & - & - & - & - & - & - \\
\hline Pier 4 & - & - & - & - & - & - \\
\hline
\end{tabular}

\begin{tabular}{|l|l|l|l|l|}
\hline Level 1 Pier Descr. & 1 & \multicolumn{1}{|c|}{2} & 3 & \multicolumn{1}{|c|}{} \\
\hline 86. Location (BF) & & - & - & - \\
\hline 87. Type & & - & - & - \\
\hline 88. Material & & - & - & - \\
\hline 89. Shape & & - & - & - \\
\hline 90. Inclined? & & - & - & - \\
\hline 91. Attack $\angle$ (BF) & & - & - & - \\
\hline 92. Pushed & & - & - & - \\
\hline 93. Length (feet) & - & - & - & - \\
\hline 94. \# of piles & & - & - & - \\
\hline 95. Cross-members & & - & - & - \\
\hline 96. Scour Condition & & - & - & - \\
\hline 97. Scour depth & $\mathbf{N}$ & - & - & - \\
\hline 98. Exposure depth & - & - & - & - \\
\hline
\end{tabular}

LFP, LTB, LB, MCL, MCM, MCR, RB, RTB, RFP

1- Solid pier, 2- column, 3- bent

1-Wood; 2- concrete; 3- metal; 4- stone

1- Round; 2- Square; 3- Pointed

Y-yes; $N$ - no

$L B$ or $R B$

0- none; 1- laterals; 2- diagonals; 3- both

0- not evident; 1- evident (comment);

2- footing exposed; 3- piling exposed;

4- undermined footing; 5- settled; 6- failed 
99. Pier comments (eg. undermined penetration, protection and protection extent, unusual scour processes, etc.):

-
-
-
-
-
-
-
-
-

100.

\section{E. Downstream Channel Assessment}

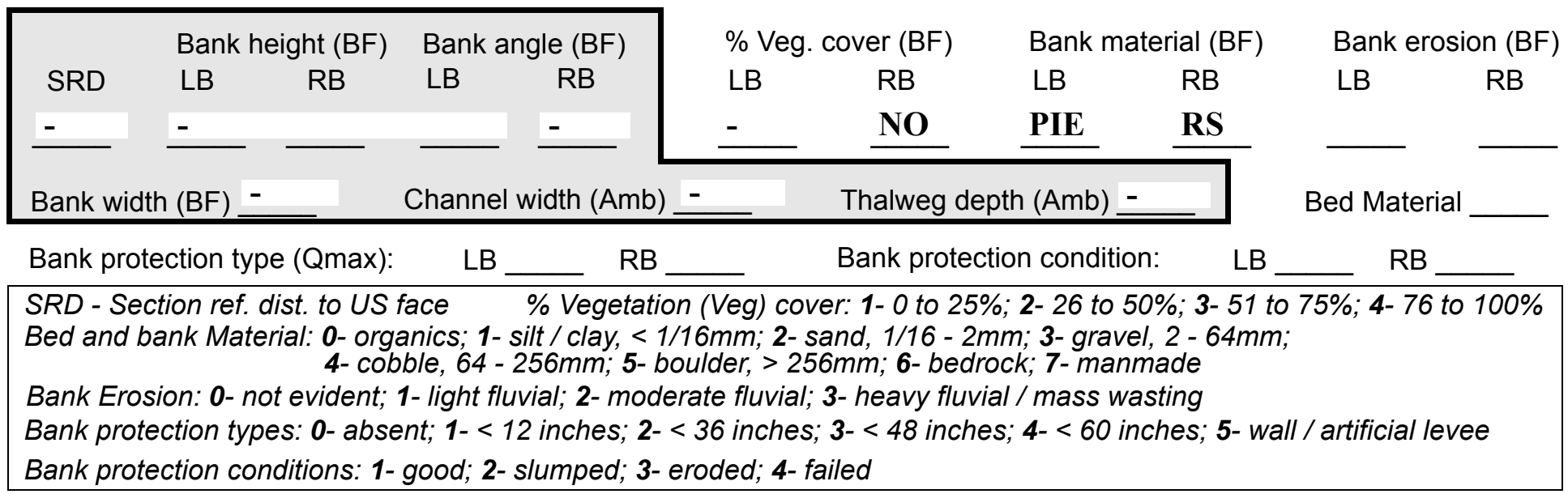

Comments (eg. bank material variation, minor inflows, protection extent, etc.):

1

1

213

21

1

1

231

0

2

**

Channel is slightly enlarged on RB from 26 feet DS to 95 feet DS, as a result of pooling and redirection of flow by breached beaver dams. The remains of the first old beaver dam is 42 feet to 51 feet downstream on the

101. Is a drop structure present? ri ( $Y$ or $N$, if $N$ type ctrl-n ds) 102. Distance: ___ feet

103. Drop: -_ feet 104. Structure material: ght (1- steel sheet pile; 2- wood pile; 3- concrete; 4- other)

105. Drop structure comments (eg. downstream scour depth):

bank. It blocks nearly half the channel from the right bank. The remains of a second old beaver dam (breached) exists at 95 feet DS.

**The right bank about five feet from bridge has some granite blocks placed on a cut bank. The protection is sparsely placed. 
106. Point/Side bar present? (Y or $N$. if $N$ type ctrl-n pb)Mid-bar distance:

Mid-bar width:

Point bar extent: feet

(US, UB, DS) to feet (US, UB, DS) positioned $\underline{\mathbf{N}}$ $\%$ LB to $\% \mathrm{RB}$ Material: $\mathbf{N O}$

Point or side bar comments (Circle Point or Side; note additional bars, material variation, status, etc.):

\section{DROP STRUCTURE}

Is a cut-bank present? (Y or if $N$ type ctrl- $n$ cb) Where? $(L B$ or $R B)$

Mid-bank distance: $\underline{\mathbf{Y}}$ Cut bank extent: $\underline{\mathbf{7 6}}$ feet $\underline{\mathbf{8}}$ (US, UB, DS) to 64 feet $\underline{\mathrm{DS}}$ (US, UB, DS)

Bank damage: $\underline{\mathbf{8 8}}$ (1-eroded and/or creep; 2- slip failure; 3- block failure)

Cut bank comments (eg. additional cut banks, protection condition, etc.):

DS

50

85

23

Is channel scour present? ( $Y$ or if $N$ type ctrl-n cs)

Mid-scour distance:

Scour dimensions: Length Width

Depth: $\mathbf{N} \quad$ Positioned -

$\%$ LB to $=$ $\%$ RB

Scour comments (eg. additional scour areas, local scouring process, etc.):

$-$

$-$

$-$

Are there major confluences? ( $Y$ or if $N$ type ctrl-n $m c)$

How many? NO

Confluence 1: Distance CUT

Confluence 2: Distance $\underline{\mathbf{S}}$ Enters on $\underline{\mathbf{B A}}$ (LB or RB)

Type $\mathbf{N K}$

(1- perennial; 2- ephemeral)

Confluence comments (eg. confluence name): (LB or $R B)$

Type (1-perennial; 2- ephemeral)

Y

\section{F. Geomorphic Channel Assessment}

107. Stage of reach evolution 4

1- Constructed

2- Stable

3- Aggraded

4- Degraded

5- Laterally unstable

6- Vertically and laterally unstable 
108. Evolution comments (Channel evolution not considering bridge effects; See HEC-20, Figure 1 for geomorphic descriptors):

18

5

0.8

25

40

An additional scour hole exists behind breached beaver dam. The scour hole is about one foot below the mean thalweg depth and is located from 49 feet DS to 75 feet DS.

$\mathbf{N}$

-

- 


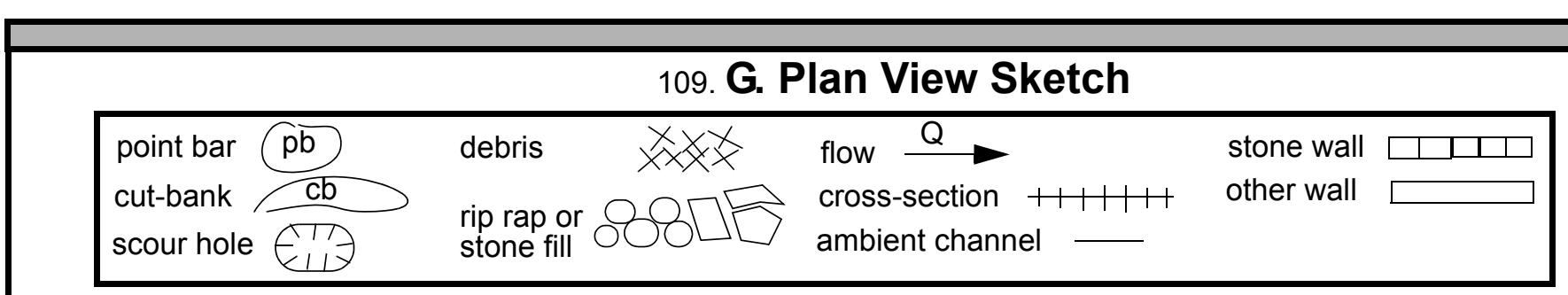


APPENDIX F:

SCOUR COMPUTATIONS 
SCOUR COMPUTATIONS

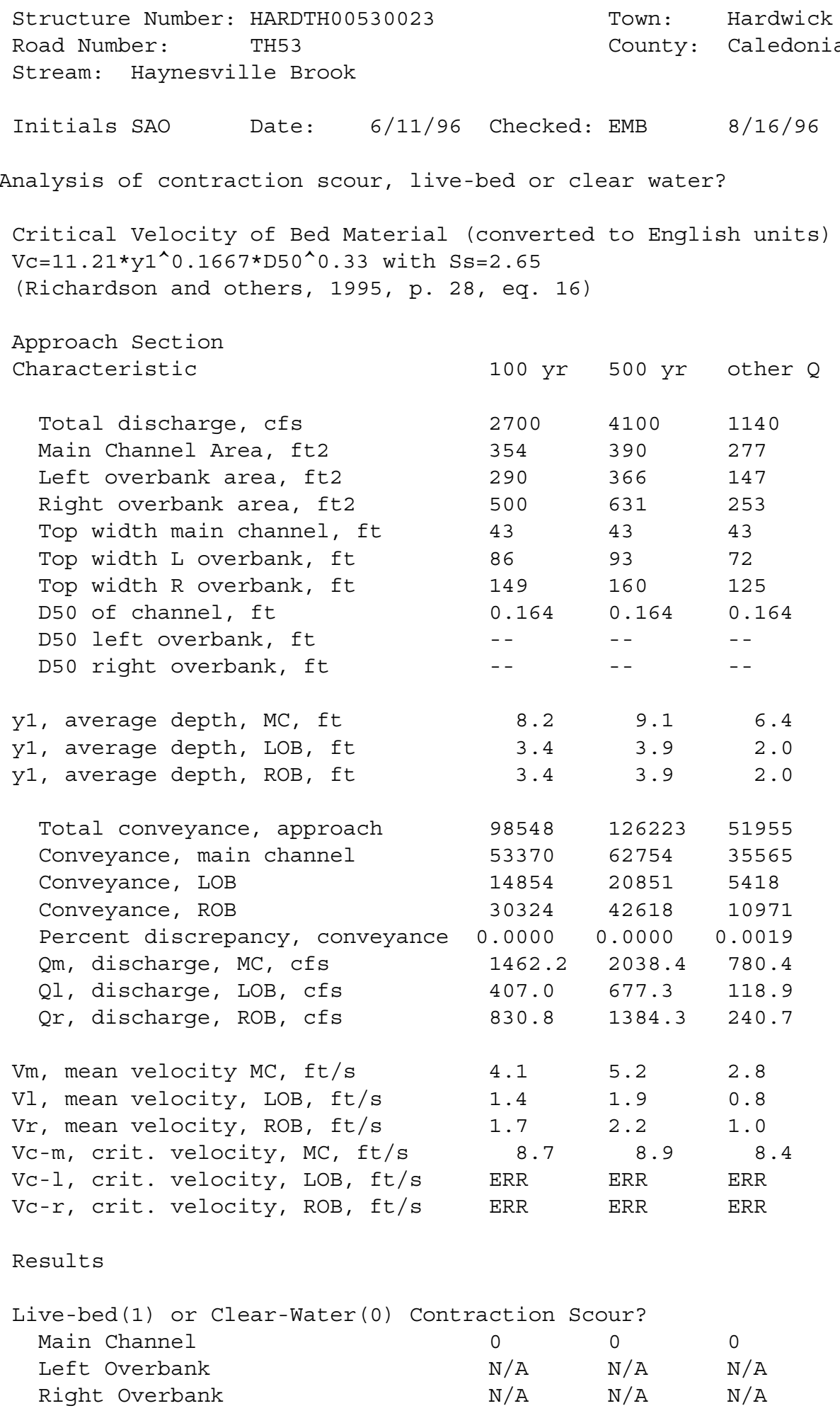


Clear water Contraction Scour in MAIN CHANNEL

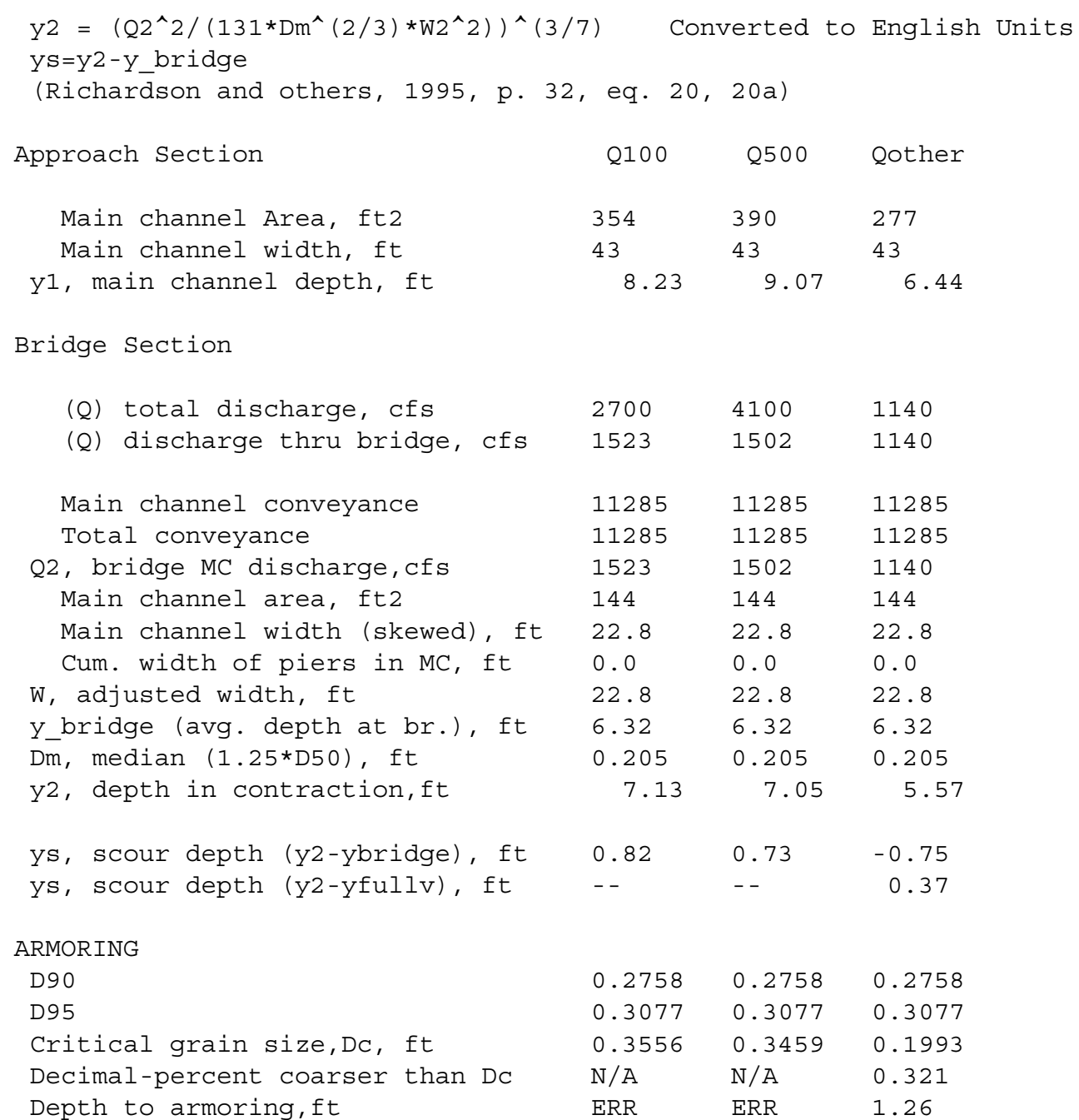

PRESSURE FLOW SCOUR COMPUTATION (contraction scour for orifice flow conditions)

\begin{tabular}{|c|c|c|c|}
\hline $\mathrm{Hb}+\mathrm{Ys}=\mathrm{Cq} * \mathrm{q} \mathrm{br} / \mathrm{Vc}$ & $C f=1$ & $.5 * \mathrm{Fr}^{\wedge} 0.4$ & $(<=1)$ \\
\hline $\begin{array}{l}\text { Chang Equation } \\
\text { (Richardson and }\end{array}$ & $\begin{array}{l}\mathrm{Hb} /(\mathrm{ya}-\mathrm{w}) \\
5-146)\end{array}$ & $-0.56)]+$ & $(<=1)$ \\
\hline & Q100 & Q500 & OtherQ \\
\hline Q thru bridge main chan, cfs & 1523 & 1502 & 1140 \\
\hline Vc, critical velocity, ft/s & 8.7 & 8.9 & 8.4 \\
\hline Vc, critical velocity, m/s & 2.651631 & 2.712588 & 2.560195 \\
\hline Main channel width (skewed), ft & 22.8 & 22.8 & 22.8 \\
\hline Cum. width of piers, ft & 0 & 0 & 0 \\
\hline adjusted width, ft & 22.8 & 22.8 & 22.8 \\
\hline
\end{tabular}


qbr, unit discharge, $f t^{\wedge} 2 / \mathrm{s}$

qbr, unit discharge, $\mathrm{m}^{\wedge} 2 / \mathrm{s}$

Area of full opening, ft^ 2

$\mathrm{Hb}$, depth of full opening, ft

$\mathrm{Hb}$, depth of full opening, $m$

Fr, Froude number MC

Cf, Fr correction factor (<=1.0)

Elevation of Low Steel, ft

Elevation of Bed, ft

Elevation of approach WS, ft

$\mathrm{HF}$, bridge to approach, ft

Elevation of WS immediately US, ft

ya, depth immediately US, ft

ya, depth immediately US, m

Mean elev. of deck, ft

$w$, depth of overflow, ft $(>=0)$

$\mathrm{Cc}$, vert contrac correction $(<=1.0)$

Ys, depth of scour (chang), ft

Abutment scour

Froehlich's Abutment Scour

$\mathrm{Ys} / \mathrm{Y} 1=2.27 * \mathrm{~K} 1 * \mathrm{~K} 2 *\left(\mathrm{a}^{\prime} / \mathrm{Y} 1\right) \wedge 0.43 * \mathrm{Fr} 1 \wedge 0.61+1$

(Richardson and others, 1995, p. 48, eq. 28)
$66.79825 \quad 65.87719 \quad 50$

$6.205154 \quad 6.119594 \quad 4.644699$

$\begin{array}{lll}143.8 & 143.8 & 143.8\end{array}$

$6.307018 \quad 6.307018 \quad 6.307018$

$1.922285 \quad 1.9222851 .922285$

$\begin{array}{lll}0.75 & 0.74 & 0.55\end{array}$

$1 \quad 1 \quad 1$

$498.24 \quad 498.24 \quad 498.24$

$491.933 \quad 491.933 \quad 491.933$

$501.49 \quad 502.34 \quad 499.69$

$\begin{array}{lll}0.11 & 0.16 & 0.05\end{array}$

$\begin{array}{lll}501.38 & 502.18 & 499.64\end{array}$

$9.447018 \quad 10.24702 \quad 7.707018$

$\begin{array}{llll}2.93568 & 3.184281 & 2.394971\end{array}$

$500.46 \quad 500.46 \quad 500.46$

$0.92 \quad 1.72 \quad 0$

$0.924034 \quad 0.924034$

$2.002157 \quad 1.703437-0.04618$

Left Abutment

Right Abutment

100 yr Q 500 yr Q Other Q 100 yr Q 500 yr Q Other Q

$\begin{array}{lcccccc}\text { (Qt), total discharge, cfs } & 2700 & 4100 & 1140 & 2700 & 4100 & 1140 \\ \text { a', abut.length blocking flow, ft } & 86.7 & 93.4 & 72.5 & 168.4 & 179.7 & 144.4 \\ \text { Ae, area of blocked flow ft2 } & 217.7 & 229.2 & 149.8 & 482.3 & 510.2 & 361.9 \\ \text { Qe, discharge blocked abut., cfs } & -- & -- & 130 & -- & -- & 505.2 \\ \text { (If using Qtotal_overbank to obtain Ve, leave Qe blank and enter Ve manually) } & \\ \text { Ve, (Qe/Ae), ft/s } & 1.44 & 1.95 & 0.87 & 2.11 & 2.70 & 1.40 \\ \text { ya, depth of f/p flow, ft } & 2.51 & 2.45 & 2.07 & 2.86 & 2.84 & 2.51\end{array}$

--Coeff., Kl, for abut. type (1.0, verti.; 0.82, verti. w/ wingwall; 0.55, spillthru) $\mathrm{K} 1$

$\begin{array}{llllll}1 & 1 & 1 & 1 & 1 & 1\end{array}$

--Angle (theta) of embankment (<90 if abut. points DS; >90 if abut. points US)

$\begin{array}{lllllll}\text { theta } & 80 & 80 & 80 & 100 & 100 & 100\end{array}$

$\begin{array}{lllllll}\text { K2 } & 0.98 & 0.98 & 0.98 & 1.01 & 1.01 & 1.01\end{array}$

$\begin{array}{llllllll}\text { Fr, froude number f/p flow } & 0.138 & 0.173 & 0.106 & 0.191 & 0.227 & 0.155\end{array}$

$\begin{array}{lllllll}\text { ys, scour depth, ft } & 10.20 & 11.45 & 7.50 & 16.71 & 18.58 & 13.09\end{array}$

HIRE equation ( $a^{\prime} /$ ya $>25$ )

$\mathrm{Ys}=4 * \mathrm{Fr}^{\wedge} 0.33 * \mathrm{Y} 1 * \mathrm{~K} / 0.55$

(Richardson and others, 1995, p. 49, eq. 29)

$\mathrm{a}^{\prime}$ (abut length blocked, ft)

86.7

93.4

72.5

168.4

179.7

144.4

yl (depth $f / p$ flow, ft)

$a^{\prime} / y^{1}$

$2.51 \quad 2.45$

2.07

2.86

2.84

2.51

$34.53 \quad 38.06$

35.09

58.80

63.29

57.62

Skew correction (p. 49, fig. 16)

0.97

0.97

0.97

1.02

1.02

1.02

Froude no. f/p flow

$0.14 \quad 0.17$

0.11

0.19

0.23

0.16

Ys w/ corr. factor K1/0.55:

$$
\begin{aligned}
& \text { vertical } \\
& \text { vertical } \mathrm{w} / \mathrm{ww}^{\prime} \mathrm{s}
\end{aligned}
$$

$9.21 \quad 9.70$

6.96

12.30

12.91

10.06

$\begin{array}{ll}7.56 & 7.96\end{array}$

5.71

10.09

10.59

8.25 

spill-through
5.07
5.34
3.83
6.77
7.10
5.53

Abutment riprap Sizing

Isbash Relationship

$\mathrm{D} 50=\mathrm{Y} * \mathrm{~K} * \mathrm{Fr} \wedge 2 /(\mathrm{SS}-1)$ and $\mathrm{D} 50=\mathrm{Y} * \mathrm{~K} *\left(\mathrm{Fr} \mathrm{F}^{\wedge}\right)^{\wedge} 0.14 /(\mathrm{SS}-1)$

(Richardson and others, 1995, p112, eq. 81,82)

\begin{tabular}{|c|c|c|c|c|c|c|}
\hline Characteristic & Q100 & Q500 & Qothe & & & \\
\hline Fr, Froude Number & 0.75 & 0.74 & 0.55 & 0.75 & 0.74 & 0.55 \\
\hline (Fr from the characteristic $V$ and & $y$ in & cracte & ection & $\therefore$ bri & secti & \\
\hline$y$, depth of flow in bridge, ft & 5.00 & 5.00 & 5.00 & 5.00 & 5.00 & 5.00 \\
\hline Median Stone Diameter for riprap at: & left & atment & & right & atment & \\
\hline Fr<=0.8 (vertical abut.) & 1.74 & 1.69 & 0.94 & 1.74 & 1.69 & 0.94 \\
\hline Fr>0.8 (vertical abut.) & $\mathrm{ERR}$ & ERR & ERR & $\mathrm{ERR}$ & ERR & ERR \\
\hline Fr $<=0.8$ (spillthrough abut.) & 1.52 & 1.48 & 0.82 & 1.52 & 1.48 & 0.82 \\
\hline Fr>0.8 (spillthrough abut.) & ERR & ERR & ERR & ERR & ERR & ERR \\
\hline
\end{tabular}

